\title{
Knowledge, Attitude, and Practice of Primary Care Physicians Regarding Common Dermatological Disorders in Abha City, Kingdom of Saudi Arabia
}

\author{
Dr Mohammed Abdullah A Al-Zahrani ${ }^{1}$, Professor Shamsun Nahar ${ }^{2}$, Dr Sami \\ Abdullah Al-Zahrani ${ }^{3}$, Dr Ramzy Ahmed Al-Zahrni ${ }^{3}$ \\ (1. MBBS, SBFM, ABFM, JBFM, ) \\ (2.MBBS, MSC (University of LONDON), PhD (University of Cambridge, UK)) \\ (3. Medical Intern, College of medicine, Albaha University, Saudi Arabia)
}

\begin{abstract}
Background:-Majorityof skin diseases are not life threatening, but the psychological effects of relativelyminor skin abnormalities can often cause more distress to the patients than other more serious medical disorders. As medical knowledge expands, family physicians face an ever-increasing challenge in diagnosis and treatment of skin disorders.
\end{abstract}

Objectives:To assess knowledge, attitudes and practice (KAP) among primary health care providers (PHCP) in Abha City regarding Common dermatological problems and correlate their level of knowledge and practice gap with their background characteristics.

Subjects and Methods: Across-sectional study was conducted included all primary health care providers (GPs and Family physicians) in Abha city. A validated selfadministered questionnaire was utilized for data collection. It included questions about socio-demographic characteristics of the participants as well as questions to assess their knowledge, attitude and practice regarding common dermatological problems.

Results: The study included 105 primary healthcare physicians with a response rate of $84.7 \%$. Forty percent of them were in the age group $31-40$ years whereas $30.5 \%$ were in the age group 31-30 years. Almost two-thirds of them (65.7\%) were males. More than half of them (59\%) were non-Saudi. More than two thirds $(69.5 \%)$ of primary healthcare physicians had insufficient knowledge regarding common dermatological disorders whereas $21.9 \%$ of them had good knowledge and only $4.8 \%$ had excellent knowledge. Attending training courses was significantly associated with sufficient knowledge, $\mathrm{p}=0.003$. Lack of guidelines, training, educational materials and time and place were the commonest reported barriers that PHC physicians` face regarding management of dermatological disorders.

Conclusions: More than two-thirds of primary health care providers had insufficient knowledge regarding management of common skin disorders. More than half of the PHC physicians strongly agreed that they should have $\mathrm{a}$ role in the managing of common dermatological disorders. The commonly reported barriers for that are lack of guidelines and training in dermatology.

\section{INTRODUCTION}

Skin diseases are very common, affecting approximately $20-33 \%$ of the population at any one time. [1]In addition, skin cancers are the most common malignancies that occur in the Caucasian population each year. [2]The majority of skin diseases are not life threatening, but the psychological effects of relatively minor skin abnormalities can often cause more distress to the patients than other more serious medical disorders. [3]The skin is very important for human being in many ways:

- It is a sensitive dynamic boundary between the body and the outside world;

- It is essential for controlling water and heat loss;

- It has defensive functions against infections and infestations, as well as protective properties against irritants, allergens and UV radiation.

- The skin is the largest organ in the body and is not a simple 'inert' barrier. 
- It is an important sensory organ that is able to distinguish pain, touch, itch, heat and cold.

- The skin is an important organ for social and sexual contact, and contains other important structures, including hair, blood vessels, nerves, sweat and sebaceous glands.-In addition, vitamin D is synthesized in the skin. Thus, skin failure can be as worthy of medical attention as cardiac or renal failure as it affects all of the functions just described. [3]Chronic suffering rather than mortality is the characteristic of most skin diseases. In addition to physical symptoms, perhaps the most significant way in which skin disease affects people is the effect it has on psychological well-being. [3]Disfiguring skin disease in visible sites such as the face (e.g. acne) can result in loss of self-esteem, depression and poorer job prospects.[4] Indeed, quality-of-life scores for people with skin disease are often worse than for people with more traditional 'medical' disorders such as angina and hypertension.[5] The skin is therefore a sensitive and dynamic organ that has a crucial and frequently underestimated social function. The study of the magnitude of skin diseases and their impacts on patient lives is captured with disciplines such as epidemiology and health services research. Further, these research arenas depend on standardized case dentitions and an understanding of the limitations of diagnostic tests and potential biases.[2]Although it is true that skin disease is rarely life threatening, its moderate morbidity rate multiplied by its high prevalence rate places skin disease among the top four chronic disease groups when entire communities are considered.[6] In addition, several important skin diseases such as skin cancer, atopic dermatitis, venous stasis ulcers and psoriasis are becoming more common.[6]Unlike most other medical specialties, dermatology as a specialty has between 1000 and 2000 diseases. However, fewer than ten categories of skin disorders account for over $70 \%$ of dermatologic consultations: skin cancer, acne, atopic dermatitis, psoriasis, viral warts, infective skin disorders, benign tumors and vascular lesions, leg ulceration, and contact dermatitis (and other eczema).[6]

\section{Rationale of the study:}

- Due to high burden of dermatological problems in our community it is important to assess knowledge, attitude and practice of primary health care physicians about it.

- $\quad$ The studies done in our area are rare and old. [24, 25, 28]

- $\quad$ So, a recent study is deeply needed to update the figures and accurately measure the KAP of Primary Health Care Physicians.

\section{Study objectives:}

This study was carried out to:

-Assess knowledge, attitudes and practice (KAP) among Primary health care providers (PHCP) in Abha City regarding Common dermatological problems.

- Correlate the level of knowledge and practice gap with background characteristics of the physicians.

-Find out the recommendations to improve the knowledge of common dermatological disorders among physicians.

\section{LITERATURE REVIEW}

The economic implications of the magnitude of skin disorders are not trivial. Various studies have assessed the economic impact of specific skin diseases and these have shown that direct costs are as high as for many other diseases. [6]Small changes in the way this balance functions can have a profound effect on a country's healthcare budget because skin disease affects so many people. Other costs such as unemployment and losing an economically viable sector of a country's workforce are also important when considered at a population level. [6]Indirect costs (e.g. the time lost from work to take care of skin problems) and the opportunity costs (i.e. costs that could be gained by doing something other than taking care of skin problems) also need to be considered in such economic evaluations.[6]The overall proportion of the population found to have any form of skin disease was 55\% (95\% confidence intervals, 49.6-61.3\%).[7]Another detailed crosssectional study of skin diseases was conducted by the first US Health and Nutrition Examination Survey on a representative population sample of 20749 persons between 1 and 74 years of age. Nearly one-third (312 per 1000 population) had one or more significant skin conditions that were considered by a dermatologist to justify evaluation by a physician at least once. [8]Both surveys, along with a trend towards an increase in consultation rates for skin disease as a whole, suggest that there is a large hidden iceberg of unmet dermatologic needs. [9]Inflammatory skin diseases such as atopic dermatitis, contact dermatitis, psoriasis, hand eczema and acne are very common in the population. Infectious skin diseases account for a large portion of skin disorders presenting to both primary care physicians and dermatologists, and skin cancer represents the most common form of human cancer, although many cancer registries probably underestimate its true incidence.[9] The past decade has seen a significant surge in the incidence of skin disease in Saudi Arabia, with almost $20 \%$ of children between the ages of 6 and 18 suffering from eczema.[10]Al Shobaili (2010) carried on a study in Al Qassim region, Saudi Arabia which included 3051 patients comprising 1786 (58.5\%) males and 1265 (41.5\%) females. Males outnumbered 
females $(\mathrm{P}<.05)$ (male-to-female ratio, 1.4:1). The mean age (standard error of the mean) of the patients was $25.3(0.27)$ years. About $71 \%$ of the patients were between 5 and 34 years of age. The top five skin diseases were eczema/ dermatitis $(19.5 \%)$, viral infections $(16.6 \%)$, pilosebaceous disorders $(14.4 \%)$, pigmentary lesions $(11.2 \%)$ and hair disorders (7.6\%). The major disorder in males was viral skin infections $(20.0 \%)$, while eczema/dermatitis $(20.7 \%)$ constituted the most prevalent skin disease in females. Seasonal variations were recorded in cases of pigmentary lesions, papulosquamous disorders and protozoal infections. [11]While Abdulrahman et al. (2008) reported that during the five year period (2001-2005), a total of 58450 cases were seen at the dermatological clinics of Riyadh Military Hospital. The incidence of dermatological diseases was more in female patients $34123(58.38 \%)$ than male patients 24327 (41.62\%). Most of the cases were clinically diagnosed. The highest number of patients was in the age group of 41-50 years. Dermatitis/ Eczemas was the most common skin disorder (21.29\%) followed by diseases of the hair (11.9\%) and acne (11.88\%). Cutaneous infections due to viruses, bacteria and fungi were seen in $9.70 \%, 2.97 \%$ and $4.5 \%$ of the patients respectively. The erythematosquamous diseases of the skin were recorded in only $4.61 \%$ of the patients; psoriasis $(2.47 \%)$ was predominantly seen in this group of patient. On the other hand out of $10.20 \%$ patients who had pigmentary disorders $3.2 \%$.were affected by inflammatory hyper pigmentation, $2.69 \%$ patients had vitiligo and $2.47 \%$ showed melasma. [12]

\begin{tabular}{|c|c|c|}
\hline GROUP & $\begin{array}{l}\text { CLINICAL } \\
\text { Morphology }\end{array}$ & $\begin{array}{l}\text { EXAMPLES OF DISEASES IN } \\
\text { THE GROUP }\end{array}$ \\
\hline $\begin{array}{l}\text { Eczemato } \\
\text { us } \\
\text { dermatiti } \\
\text { s }\end{array}$ & $\begin{array}{l}\text { Erythematous } \\
\text { macules, } \\
\text { papules, } \\
\text { vesicles, } \\
\text { lichenification, } \\
\text { fine scaling, } \\
\text { excoriations, } \\
\text { crusting }\end{array}$ & $\begin{array}{l}\text { Contact dermatitis, atopic dermatitis, } \\
\text { stasis dermatitis, photodermatitis, } \\
\text { exfoliative dermatitis }\end{array}$ \\
\hline $\begin{array}{l}\text { Maculop } \\
\text { apular } \\
\text { eruptions }\end{array}$ & $\begin{array}{l}\text { Macules, } \\
\text { erythema, } \\
\text { papules }\end{array}$ & $\begin{array}{l}\text { Viral exanthems, drug } \\
\text { hypersensitivity } \\
\text { Kawasaki disease, vasculitic, } \\
\text { purpuric eruptions }\end{array}$ \\
\hline $\begin{array}{l}\text { Papulosq } \\
\text { uamous } \\
\text { dermatos } \\
\text { es }\end{array}$ & $\begin{array}{l}\text { Papules, } \\
\text { plaques, and } \\
\text { erythema with } \\
\text { scales }\end{array}$ & $\begin{array}{l}\text { Psoriasis, reactive arthritis, } \\
\text { pityriasisrosea, lichen planus, } \\
\text { seborrheic dermatitis, } \\
\text { ichthyosis, secondary syphilis, } \\
\text { mycosis fungoides }\end{array}$ \\
\hline $\begin{array}{l}\text { Vesiculo } \\
\text { bullous } \\
\text { diseases }\end{array}$ & $\begin{array}{l}\text { Vesicles, } \\
\text { bullae, } \\
\text { erythema }\end{array}$ & $\begin{array}{lr}\text { Herpes simplex and zoster, } \\
\text { hand-foot-and-mouth disease, } \\
\text { insect bites, bullous } & \text { impetigo, } \\
\text { scalded skin } & \text { syndrome, } \\
\text { pemphigus, } & \text { bullous } \\
\text { pemphigoid, } & \text { dermatitis } \\
\text { herpetiformis, } & \text { porphyria } \\
\text { cutaneatarda, } & \text { erythema } \\
\text { multiforme } & \\
\end{array}$ \\
\hline $\begin{array}{l}\text { Pustular } \\
\text { diseases }\end{array}$ & $\begin{array}{l}\text { Pustules, cysts, } \\
\text { erythema }\end{array}$ & $\begin{array}{l}\text { Acne vulgaris rosacea, pustular } \\
\text { psoriasis, folliculitis }\end{array}$ \\
\hline $\begin{array}{l}\text { Urticaria } \\
\text { and } \\
\text { cellulitis }\end{array}$ & $\begin{array}{l}\text { Wheals and } \\
\text { figured, raised } \\
\text { erythema, } \\
\text { scaling }\end{array}$ & $\begin{array}{lr}\text { Urticaria, } & \text { erythema } \\
\text { annularecentrifugum, } & \text { and } \\
\text { erysipelas } & \end{array}$ \\
\hline $\begin{array}{l}\text { Nodular } \\
\text { lesions }\end{array}$ & $\begin{array}{lr}\text { Nodules and } \\
\text { tumors, some } \\
\text { associated with } \\
\text { erosions and } \\
\text { ulceration }\end{array}$ & $\begin{array}{l}\text { Benign and malignant tumors- } \\
\text { basal cell cancer, squamous cell } \\
\text { cancer, rheumatoid nodules, } \\
\text { xanthomas }\end{array}$ \\
\hline
\end{tabular}




\begin{tabular}{|l|l|l|}
\hline $\begin{array}{l}\text { Telangiectasia, } \\
\text { atrophic, } \\
\text { scarring, } \\
\text { ulcerative } \\
\text { diseases }\end{array}$ & $\begin{array}{l}\text { Atrophic, } \\
\text { sclerotic } \\
\text { telangiectasia, } \\
\text { ulcerative } \\
\text { changes }\end{array}$ & $\begin{array}{l}\text { Connective tissue diseases, } \\
\text { radiation dermatitis, lichen } \\
\text { sclerosus et atrophicus, vascular } \\
\text { insufficiency (arterial and } \\
\text { venous), pyoderma } \\
\text { gangrenosum }\end{array}$ \\
\hline $\begin{array}{l}\text { Hyper-melanosis } \\
\text { and hypo- } \\
\text { melanosis }\end{array}$ & $\begin{array}{l}\text { Increased and } \\
\text { decreased } \\
\text { melanin } \\
\text { deposition in } \\
\text { skin }\end{array}$ & $\begin{array}{l}\text { Acanthosis nigricans, cafe au } \\
\text { lait spots, vitiligo, tuberous } \\
\text { sclerosis, xeroderma } \\
\text { pigmentosum, melasma, } \\
\text { freckles }\end{array}$ \\
\hline
\end{tabular}

Table I: Morphology-based classification of major skin disorders. [13]

People with skin complaints obtain help from various sources, including self-help, advice from pharmacists, treatment from primary care physicians, and services from other specialists. For example, of 291 individuals complaining of acne/spots/greasy skin, $47 \%$ took no action, $34 \%$ used or bought an over-the-counter preparation, and $12 \%$ used medicines prescribed by a doctor; the remaining $7 \%$ used home remedies.[14]

\section{Primary care management}

(This area of competence is not limited to dealing with the management of the practice.)

This means that as a General Practitioner (GP) you should:

1. Demonstrate appropriate history-taking for patients with skin problems, including family history, chemical contacts, occupation and drug usage.

2. Recognize the importance of skin-specific symptoms, e.g. itching and rash distribution.

3. Understand how to recognize common skin conditions in primary care, e.g. eczemas, psoriasis and infections, and instigate appropriate treatment.

4. Be able to distinguish benign from malignant skin conditions and make appropriate referrals.

5. Recognize rarer but potentially important conditions and know when to refer to secondary care, e.g. bullous disorders and vasculitis.

6.Recognise emergency skin conditions, e.g. erythroderma, anaphylaxis and herpetic eczema, and act appropriately.

7. Be aware of local, alternative referral resources such as GPs with a Special Interest or specialist nurse practitioners.

8. Know about shared care protocols with secondary care for the follow up of patients with skin cancer/lichen sclerosis et atrophicus and, where negotiated with the secondary care provider, those on isotretinoin.

9. Consider reviewing all referrals to establish whether the input of secondary care is 'value added' and to establish any learning points for similar cases (i.e. meeting doctors' educational needs (DENS). [15]

The current US health care system relies heavily on primary care clinics to manage a variety of conditions, including dermatologic problems. In fact, dermatologists treat only 30\%-40\% of patients with skin disease. This leaves the majority of skin disorders to be seen by clinicians in other specialties, $22 \%$ of whom are family physicians.[16]Studies in the mid 1990s reported that many physicians provided suboptimal care for patients with skin disorders. [17-18] In one study, dermatologists determined that only $40 \%$ of patients with skin disease received optimal care. [19]As medical knowledge expands, family physicians face an ever-increasing challenge in diagnosis and treatment of skin disorders. They must be skilled in disease recognition and management, as well as understanding when to refer patients to the appropriate specialist. Although it might be expected that family physicians refer patients for more uncommon skin disorders, it is notable that primary care physicians often refer patients to dermatologic specialists for common and straightforward skin conditions. [20] This behavior may be a reflection of the quantity and quality of dermatologic training received during family medicine residency.Farah et al. (2008) reported that Skin conditions accounted for $8 \%$ of all visits to family physicians in 2002-2005. The five most common skin disorders diagnosed by family physicians were dermatitis, pyoderma, tinea, benign neoplasms, and candida. The top 20 diagnoses accounted for $70 \%$ of the visits. The three most commonly prescribed medication classes for skin problems from 2002-2005 were antihistamines, topical anti-infectives, and adrenal corticosteroids. [21]

\section{Why is health services research important for dermatology?}

Health services research refers to the study of healthcare services and interventions in the real-life setting. Information from health services research helps patients and policymakers to make informed decisions and improve the quality of healthcare services. Unlike traditional clinical trials, health services research does not focus on physiologic endpoints. Instead, parameters include clinical outcomes, quality of life outcomes, quality 
of care, cost, patient satisfaction, usage of healthcare services, and access to such services. Health services research also informs decision-makers about the best ways to deliver appropriate care with societal constraints. Specifically, with limited healthcare resources, the most cost-effective treatments for skin disease must be elucidated. [23]

Information from health services research may provide answers to the following questions:

- What is the quality-of-life impact?

- What subpopulations utilize dermatologists?

- What barriers exist to healthcare access?

- Is this new therapy cost-effective relative to existing ones?

- Are patients satisfied with their healthcare delivery?

- What standards exist, and what evidence supports such standards, for delivering specific health care?

- Are most physicians complying with existing standards of care? [23]

\section{Situation of Dermatological diseases in Saudi Arabia:}

There are rare studies which describe epidemiology of skin disease in Saudi Arabia. One of these studies was the one conducted in south part of Saudi Arabia on 1995 by Bahamdan and Egere. They attempted to analyze the pattern of skin diseases seen in the dermatology unit of Asir Central Hospital, Abha, Southern Saudi Arabia, during a 12-month period from March 1992 to March 1993. All new patients who were seen for dematological complaints in the skin clinics, emergency room or in the wards were studied prospectively. A total of 1285 dermatoses were diagnosed in 1223 patients during the 12-month study period. Out of the top 12 groups diseases, eczema/dermatitis (25.68\%) came first, followed by viral infections. Among the eczema group, atopic eczema accounted for $53.64 \%$ and was most frequently observed in children (110/177 or $62.14 \%$ ) compared to adults. The main causes of superficial mycoses were dermatophytosis and candidiasis. Psoriasis was the most common papulosquamous disorder. Scabies was seen in expatriate Egyptians and Asiatics only. Primary pyogenic infections of the skin were uncommon. The pattern of skin diseases in Saudi Arabia shows a predominance of eczema. Viral infections and dermatophytosis are the most common infective dermatoses, while pyogenic infections are relatively uncommon. [24]More recent study was conducted in southwestern Saudi in 2004 by Shelleh and Al-Hatiti (2004). They recorded 1192 new patients within the study period, 37\% had one of the dermatitis or eczema group of diseases, $12.75 \%$ had acne, $7 \%$ had vitiligo, $5.9 \%$ had viral infections 5.6\% had superficial mycoses, 5\% had bacterial infections, $1.51 \%$ had psoriasis and only $1.1 \%$ had lichen planus. By comparison, the incidence of dermatitis or eczema, acne and vitiligo was slightly higher in Najran compared to other regions such as Asir, Hail, Al-Jouf and Jeddah, KSA. Owing probably to the genetic predilection of Najran community to these disorders. Najran was lower than others in psoriasis and in lichen planus, but in minimal deviations. However, Najran was comparable to others in infective diseases including viral warts, superficial mycoses and bacterial infections.[25]Dermatology literature boasts about the superiority of the dermatologist in diagnostic ability, cost savings, and cancer prevention when compared with primary care physicians. [26-27] One of important study done in Saudi Arabia demonstrated that "Primary Care Physicians (PCPs) with a short period of specific clinical training in dermatology perform better in identifying, diagnosing and managing skin disorders than those without. Such training for PCPs should be considered to provide more effective delivery of health care. [28]

\section{METHODS AND MATERIALS}

This is cross sectional study conducted in Abha city, the capital of Asser, lies in the southwestern part of Saudi Arabia, about $3100 \mathrm{~m}$ above sea level. Its climate is temperate, with daily temperatures ranging from 5 to $32 \mathrm{C}$, and an annual rainfall of 450 millimeters. [29] Because of limited number in PHC centers in Abha city [sixteen centers] all PHC physicians were invited to participate in this study including GPs and Family physicians.

Six PHCC are:

Al-Manhal, Al-Qabel, Al-Muadhfen, Al-Mansak, Shamasan,Al-Nomais, Zera, Azizia, Sheba, Al-Ssenia , Umsara, ShamalElmatar, Al-Hamela, Al-Emara, Hay ElKhamis , Hay Eldhba'at .

Inclusion criteria:

- Physicians affiliated to a primary care center within the study area since at least 3 months.

- On duty during data collection period.

Exclusion criteria:

- Physicians affiliated to a primary care center within the study area less than 3 months.

- Not on duty during data collection period.

- Physicians who refuse to participate in the study. Validated questionnaire was used to assess the following items:

- Knowledge of physicians: The percentage of correct answers was calculated. 
- Attitude: was measured on likert scale regarding their intention to learn about common dermatological problems.

- Practice: was measured by if they practice or not. [30]

The researcher distributed the self-administered questionnaire to the target population by direct contact with them. Care was taken to not disturb the healthcare worker's duty. The researcher was available to clarify any issue and the questionnaires were collected soon after encounter. The data were verified by hand then were coded and entered to a personal computer.Thanks, and appreciations were used to encourage the participants to be involved in the study.Background information included age, gender, Nationality, and place obtaining medical education.Physician practice characteristics included specialty, type and year of practice, and frequency of communicating with the patients. Data were entered and analyzed by SPSS version 20. Descriptive statistics was applied using frequency and percentage since all data were categorized. Analytical statistics was applied using chi-square test for testing the difference or association between two categorical variables. Significance was determined at $\mathrm{p}$ value $<0.05$. Physician`s` knowledge regarding common skin disorders was categorized according to the mean knowledge score into four categories; insufficient (mean score $<60 \%$ ), good (mean score $60-75 \%$ ), very good (mean score $>75-85 \%$ ) and excellent (mean score $>85 \%$ ). Those whose mean knowledge score was above $60 \%$ were considered having sufficient knowledge for statistical analysis.

Before Interviewing, informed consent was asked from all respondents. All of them had the right not to participate in the study or withdraw from it prior to completion. The researcher explained the purpose of the study to all participants. This pre-measurement education is an important part. Confidentiality and privacy were guaranteed for all participants.

\section{RESULTS}

Out of 138 primary healthcare providers invited to participate in the present study, 14 were excluded from the analysis because they joined their PHC for duration of three months or less. Thus, 124 were eligible and 105 responded giving a response rate of $84.7 \%$.The study included 105 primary health care physicians. Forty percent of them were in the age group 31-40 years whereas 30.5\% were in the age group 31-30 years. Almost two-thirds of them (65.7\%) were males. More than half of them (59\%) were non-Saudi. Majority of the participants (84.8\%) had MBBS degree of qualification whereas 5.7\% had board degree. Almost a third of them (35.2\%) were family medicine residents while $61 \%$ were general practitioners and only $3.8 \%$ were family medicine consultants. Majority of the respondents (81.9\%) joined work at PHCC since more than 3 months.

\begin{tabular}{|l|l|l|l|}
\hline Variables & Categories & Number & Percentage \\
\hline Age in years & $21-30$ & 32 & 30.5 \\
& $31-40$ & 42 & 40.0 \\
& $41-50$ & 27 & 25.7 \\
& $>50$ & 4 & 3.8 \\
\hline Gender & Male & 69 & 65.7 \\
& Female & 36 & 34.3 \\
\hline Nationality & Saudi & 43 & 41.0 \\
& Non-Saudi & 62 & 59.0 \\
\hline Last qualification & MBBS & 89 & 84.8 \\
& Diploma & 6 & 5.7 \\
& Master & 4 & 3.8 \\
& Board & 6 & 5.7 \\
\hline Profession & General practitioner & 64 & 61.0 \\
& FM resident & 37 & 35.2 \\
& FM consultant & 4 & 3.8 \\
\hline
\end{tabular}

Table 2: Personal characteristics of the primary health care providers in Abha City.

As shown in table 3, almost a third of the primary health care physicians (34.3\%) claimed that they managing more than 40 patients per day. Majority of them (85.7\%) reported that they had no educational activities in Dermatology at PHCC. As well as $91.4 \%$ reported that there were no registers on Dermatology in PHCC and 95.2\% cited that haven`t guidelines for management of dermatological disorders. Forty percent of them responded that they managed between 6 and 10 patients with dermatological disorders monthly where as $10.5 \%$ of them managed more than twenty patients monthly. Half of the participants reported that their PHCC serving 5000 persons or less. 


\begin{tabular}{|c|c|c|c|}
\hline Variables & Categories & Number & Percentage \\
\hline $\begin{array}{l}\text { Number of patients managed } \\
\text { per day }\end{array}$ & $\begin{array}{l}\leq 20 \\
21-40 \\
>40\end{array}$ & $\begin{array}{l}29 \\
40 \\
36\end{array}$ & $\begin{array}{l}27.6 \\
38.1 \\
34.3\end{array}$ \\
\hline $\begin{array}{l}\text { Educational activities in } \\
\text { Dermatology at PHCC }\end{array}$ & $\begin{array}{l}\text { Yes } \\
\text { No }\end{array}$ & $\begin{array}{l}15 \\
90\end{array}$ & $\begin{array}{l}14.3 \\
85.7\end{array}$ \\
\hline $\begin{array}{l}\text { Data or registers on } \\
\text { dermatology in PHCC }\end{array}$ & $\begin{array}{l}\text { Yes } \\
\text { No }\end{array}$ & $\begin{array}{l}9 \\
96\end{array}$ & $\begin{array}{l}8.6 \\
91.4\end{array}$ \\
\hline $\begin{array}{l}\text { Do you have guidelines for } \\
\text { management } \\
\text { dermatological disorders in } \\
\text { your center }\end{array}$ & $\begin{array}{l}\text { Yes } \\
\text { No }\end{array}$ & $\begin{array}{l}5 \\
100\end{array}$ & $\begin{array}{l}4.8 \\
95.2\end{array}$ \\
\hline $\begin{array}{l}\text { Number of patients with } \\
\text { dermatological } \\
\text { managed monthly }\end{array}$ & $\begin{array}{l}\leq 5 \\
6-10 \\
11-20 \\
>20\end{array}$ & $\begin{array}{l}30 \\
42 \\
22 \\
11\end{array}$ & $\begin{array}{l}28.5 \\
40.0 \\
21.0 \\
10.5\end{array}$ \\
\hline $\begin{array}{l}\text { Total population served by } \\
\text { PHCC }\end{array}$ & $\begin{array}{l}\leq 5000 \\
5001-10000 \\
>10000\end{array}$ & $\begin{array}{l}42 \\
31 \\
11\end{array}$ & $\begin{array}{l}50.0 \\
36.9 \\
13.1\end{array}$ \\
\hline
\end{tabular}

Table 3: Work-related characteristics of the primary health care providers in Abha City.

As obvious from figure 1, more than two thirds $(69.5 \%)$ of primary healthcare physicians had insufficient knowledge regarding common dermatological disorders whereas $21.9 \%$ of them had good knowledge and only $4.8 \%$ had excellent knowledge.

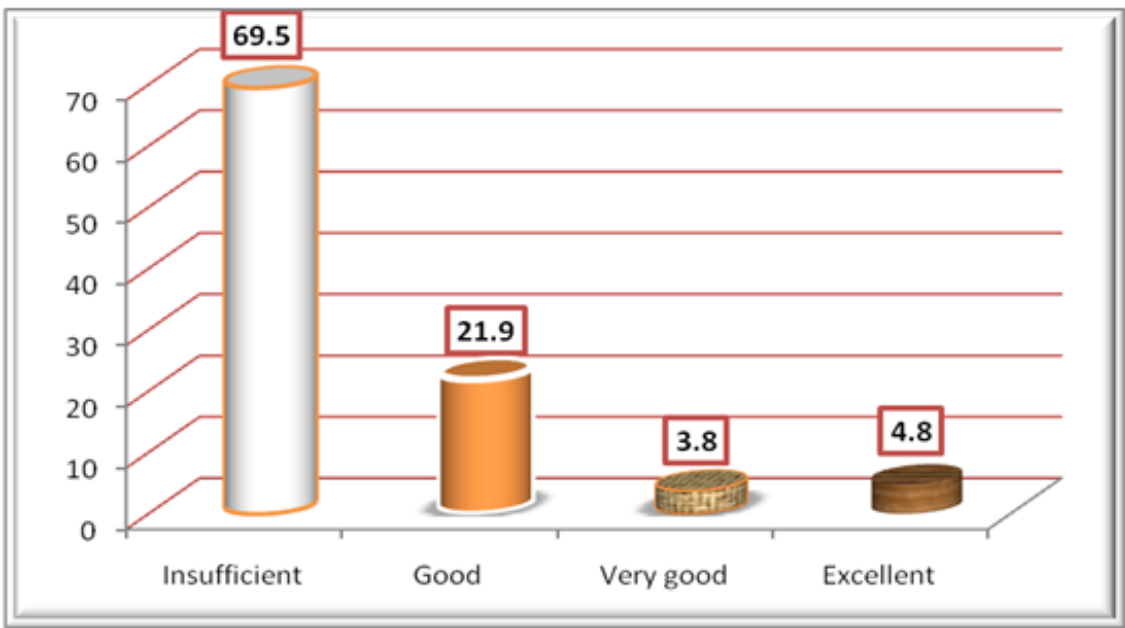

Figure 1: Knowledge level of health care providers (PHCP) in Abha City regarding common dermatological problems.

Table 4 shows that physicians who had degrees more that bachelor showed significant higher sufficient level of knowledge regarding common dermatological problems compared to those who had Bachelor $(83.3 \%$, $75 \%$ and $50 \%$ of those having Diploma, master and board, respectively compared to $23.6 \%$ of those having bachelor). All consultants compared to $37.8 \%$ of residents and $21.9 \%$ of GPs had sufficient knowledge. This difference was statistically significant, $\mathrm{p}=0.002$. PHC providers who joined the PHCC for a duration of three months or less showed significant higher rate of sufficient knowledge regarding common dermatological problems $(52.6 \%$ versus $25.6 \%, \mathrm{p}=0.02)$. As illustrated from table 5 , more than half $(51.7 \%)$ of physicians who attended training courses in dermatology had sufficient knowledge regarding management of common dermatological disorders compared to $22.4 \%$ among those who did not attend training courses. The difference was statistically significant, $\mathrm{p}=0.003$. 


\begin{tabular}{|c|c|c|c|}
\hline & \multicolumn{2}{|c|}{$\begin{array}{l}\text { Knowledge of common dermatological } \\
\text { problems }\end{array}$} & \multirow{2}{*}{$\begin{array}{l}\text { Chi-square } \\
\text { value } \\
\text { (P-value) }\end{array}$} \\
\hline & $\begin{array}{l}\text { Insufficient } \\
N=73 \\
N(\%)\end{array}$ & \begin{tabular}{|l} 
Sufficient \\
$\mathbf{N}=32$ \\
$\mathrm{~N}(\%)$
\end{tabular} & \\
\hline $\begin{array}{l}\text { Age (years) } \\
21-30(n=32) \\
31-40(n=42) \\
41-50(n=27) \\
>50(n=4)\end{array}$ & $\begin{array}{l}24(75.0) \\
30(71.4) \\
18(66.7) \\
1(25.0)\end{array}$ & $\begin{array}{l}8(25.0) \\
12(28.6) \\
9(33.3) \\
3(75.0) \\
\end{array}$ & $\begin{array}{l}4.37 \\
(0.224)\end{array}$ \\
\hline $\begin{array}{l}\text { Gender } \\
\text { Male }(n=69) \\
\text { Female }(n=36)\end{array}$ & $\begin{array}{l}48(69.6) \\
25(69.4)\end{array}$ & \begin{tabular}{|l}
$21(30.4)$ \\
$11(30.6)$ \\
\end{tabular} & $\begin{array}{l}\mathbf{0 . 0 0 1} \\
(0.990)\end{array}$ \\
\hline $\begin{array}{l}\text { Nationality } \\
\text { Saudi }(n=43) \\
\text { Non-Saudi }(n=62)\end{array}$ & $\begin{array}{l}28(65.1) \\
45(72.6)\end{array}$ & $\begin{array}{l}15(34.9) \\
17(27.4) \\
\end{array}$ & $\begin{array}{l}0.67 \\
(0.414)\end{array}$ \\
\hline $\begin{array}{l}\text { Education } \\
\text { MBBS }(n=89) \\
\text { Diploma }(n=6) \\
\text { Master }(n=4) \\
\text { Board }(n=6) \\
\end{array}$ & $\begin{array}{l}68(76.4) \\
1(16.7) \\
1(25.0) \\
3(50.0) \\
\end{array}$ & \begin{tabular}{|l}
$21(23.6)$ \\
$5(83.3)$ \\
$3(75.0)$ \\
$3(50.0)$ \\
\end{tabular} & $\begin{array}{l}14.72 \\
(0.002)\end{array}$ \\
\hline $\begin{array}{l}\text { Profession } \\
\text { GP }(n=64) \\
\text { FM resident }(n=37) \\
\text { FM consultant }(n=4)\end{array}$ & $\begin{array}{l}50(78.1) \\
23(62.2) \\
0(0.0)\end{array}$ & $\begin{array}{l}14(21.9) \\
14(37.8) \\
4(100)\end{array}$ & $\begin{array}{l}12.31 \\
(\mathbf{0 . 0 0 2})\end{array}$ \\
\hline
\end{tabular}

Table 4: Association between physicians` personal characteristics and their knowledge about common dermatological problems.

\begin{tabular}{|l|c|l|l|l|}
\hline & Categories & \multicolumn{2}{|l|}{$\begin{array}{l}\text { Knowledge of common } \\
\text { dermatological problems }\end{array}$} & $\begin{array}{l}\text { Chi-square } \\
\text { value } \\
\text { (P-value) }\end{array}$ \\
\cline { 3 - 5 } & & $\begin{array}{l}\text { Insufficient } \\
\mathbf{N = 7 3} \\
\mathbf{N}(\%)\end{array}$ & $\begin{array}{l}\text { Sufficient } \\
\mathbf{N = 3 2} \\
\mathbf{N}(\%)\end{array}$ & \\
\hline $\begin{array}{l}\text { Training course } \\
\text { in dermatology }\end{array}$ & No (76) & $59(77.6)$ & $17(22.4)$ & $\begin{array}{c}\mathbf{8 . 5 4} \\
(\mathbf{0 . 0 0 3})\end{array}$ \\
\hline
\end{tabular}

Table 5: Association between physicians`attendance of training courses in dermatology and their knowledge about common dermatological disorders.

Table 6 presents the practice of primary healthcare providers in Abha in the management of common dermatological problems. Majority of them reported that they treat patients with dermatitis $(91.4 \%)$ and treat patients with acne (96.2\%). Less than half of them reported that they advice patients with acne about diet $(46.7 \%)$ while more than half of them $(55.2 \%)$ cited that they think that stress is the most important factor for in the aetiology of dermatitis, psoriasis and acne and 56.2\% of them straight away refer someone with rash to dermatologist. Almost two-thirds of them (64.8\%) reported that they advice patients with dermatitis about diet and more than a third of them $(37.1 \%)$ claimed that they look at the feet of the person who has rash on the groin while $40 \%$ of them look at the feet of the person who has rash on the hand. Only $11.4 \%, 6.7 \%$ and $3.8 \%$ of them reported that they know how much cream is needed to cover the body, take scraping for fungal culture and take punch biopsy, respectively.

\begin{tabular}{|c|c|c|}
\hline Questions & $\begin{array}{l}\text { Yes } \\
\mathbf{N}(\%) \\
\end{array}$ & $\begin{array}{l}\text { No } \\
\text { N (\%) }\end{array}$ \\
\hline Treat the patient with dermatitis? & $96(91.4)$ & $9(8.6)$ \\
\hline Treat the patient with acne? & $101(96.2)$ & $4(3.8)$ \\
\hline
\end{tabular}




\begin{tabular}{|l|l|l|}
\hline Advice the patient with acne about diet? & $49(46.7)$ & $\mathbf{5 6}(\mathbf{5 3 . 3})$ \\
\hline Advice the patient with dermatitis about diet? & $\mathbf{6 8}(\mathbf{6 4 . 8})$ & $\mathbf{3 7}(\mathbf{3 5 . 2})$ \\
\hline $\begin{array}{l}\text { Think that stress is the most important factor for in the } \\
\text { aetiology of dermatitis, Psoriasis and acne? }\end{array}$ & $\mathbf{5 8}(\mathbf{5 5 . 2})$ & $\mathbf{4 7}(\mathbf{4 4 . 8 )}$ \\
\hline Look at the feet of the person who has rash on the groin? & $\mathbf{3 9}(\mathbf{3 7 . 1})$ & $\mathbf{6 6}(62.9)$ \\
\hline Look at the feet of the person who has rash on the hand? & $\mathbf{4 2 ( 4 0 . 0 )}$ & $\mathbf{6 3}(\mathbf{6 0 . 0})$ \\
\hline Straight away refer someone with rash to dermatologist? & $\mathbf{5 9}(\mathbf{5 6 . 2})$ & $\mathbf{4 6}(\mathbf{4 3 . 8})$ \\
\hline Take scraping for fungal culture? & $\mathbf{7 ( 6 . 7 )}$ & $\mathbf{9 8}(\mathbf{9 3 . 3})$ \\
\hline Take punch biopsy? & $\mathbf{4 ( 3 . 8 )}$ & $\mathbf{1 0 1}(\mathbf{9 6 . 2 )}$ \\
\hline Know how much cream is needed to cover the body? & $\mathbf{1 2 ( 1 1 . 4 )}$ & $\mathbf{9 3}(\mathbf{8 8 . 6})$ \\
\hline
\end{tabular}

Table 6: Practice of primary healthcare providers in Abha regarding management of common dermatological problems.

Table 7 shows that $42.9 \%$ of physicians who reported giving advice to patients with acne about diet had sufficient knowledge regarding common dermatological problems compared to $19.6 \%$ among those who did not give advice to acne patients about diet, this difference was statistically significant, p-0.010. Physicians who reported looking at the feet of the person who has rash on the groin showed higher significant sufficient knowledge about common dermatological problems compared to those who did not report such practice $53.8 \%$ versus $16.7 \%, \mathrm{p}<0.001$ ). Similarly, physicians who reported looking at the feet of the person who has rash on the hand showed higher significant sufficient knowledge about common dermatological problems compared to those who did not report such practice $(50 \%$ versus $17.5 \%, \mathrm{p}<0.001)$.Physicians who straight away refer patients with rash to dermatologist showed lower level of sufficient knowledge regarding common dermatological problems compared to those who did not report such practice $(22 \%$ versus $41.3 \%)$. This difference was statistically significant. Contrary to that, physicians who knew how much cream is needed to cover the body reported significantly higher sufficient knowledge of common dermatological problems than those who did not report such knowledge ( $75 \%$ versus $24.7 \%$, $\mathrm{p}=0.001$ ).

\begin{tabular}{|c|c|c|c|c|}
\hline & & \multicolumn{2}{|c|}{$\begin{array}{l}\text { Knowledge of common } \\
\text { dermatological } \\
\text { problems }\end{array}$} & \multirow{2}{*}{$\begin{array}{l}\text { Chi- } \\
\text { square } \\
\text { value } \\
\text { (P-value) }\end{array}$} \\
\hline & & $\begin{array}{l}\text { Insufficient } \\
\mathbf{N}=73 \\
\mathrm{~N}(\%)\end{array}$ & $\begin{array}{l}\text { Sufficient } \\
\mathbf{N}=32 \\
\mathbf{N}(\%)\end{array}$ & \\
\hline $\begin{array}{l}\text { Treat the patient } \\
\text { with dermatitis? }\end{array}$ & $\begin{array}{l}\text { Yes } \\
\text { No }\end{array}$ & $\begin{array}{l}66(68.8) \\
7(77.8) \\
\end{array}$ & $\begin{array}{l}30(31.3) \\
2(22.2)\end{array}$ & $(0.574)^{*}$ \\
\hline $\begin{array}{l}\text { Treat the patient } \\
\text { with acne? }\end{array}$ & $\begin{array}{l}\text { Yes } \\
\text { No }\end{array}$ & $\begin{array}{l}71(70.3) \\
2(50.0)\end{array}$ & $\begin{array}{l}30(29.7) \\
2(50.0)\end{array}$ & $(0.356)^{*}$ \\
\hline $\begin{array}{l}\text { Advice the patient } \\
\text { with acne about } \\
\text { diet? }\end{array}$ & $\begin{array}{l}\text { Yes } \\
\text { No }\end{array}$ & $\begin{array}{l}28(57.1) \\
45(80.4)\end{array}$ & $\begin{array}{l}21(42.9) \\
11(19.6)\end{array}$ & $(0.010)$ \\
\hline $\begin{array}{l}\text { Advice the patient } \\
\text { with dermatitis } \\
\text { about diet? }\end{array}$ & $\begin{array}{l}\text { Yes } \\
\text { No }\end{array}$ & $\begin{array}{l}48(70.6) \\
25(67.6)\end{array}$ & $\begin{array}{l}20(29.4) \\
12(32.4)\end{array}$ & $(0.748)$ \\
\hline $\begin{array}{l}\text { Think that stress is } \\
\text { the most important } \\
\text { factor for in the } \\
\text { aetiology } \\
\text { dermatitis, } \\
\text { Psoriasis and acne? }\end{array}$ & $\begin{array}{l}\text { Yes } \\
\text { No }\end{array}$ & $\begin{array}{l}41(70.7) \\
32(68.1)\end{array}$ & $\begin{array}{l}17(29.3) \\
15(31.9)\end{array}$ & $(\mathbf{0 . 7 7 3})$ \\
\hline $\begin{array}{l}\text { Look at the feet of } \\
\text { the person who has }\end{array}$ & $\begin{array}{l}\text { Yes } \\
\text { No }\end{array}$ & $\begin{array}{l}18(46.2) \\
55(83.3)\end{array}$ & $\begin{array}{l}21(53.8) \\
11(16.7)\end{array}$ & $(<0.001)$ \\
\hline
\end{tabular}




\begin{tabular}{|c|c|c|c|c|}
\hline rash on the groin? & & & & \\
\hline $\begin{array}{l}\text { Look at the feet of } \\
\text { the person who has } \\
\text { rash on the hand? }\end{array}$ & $\begin{array}{l}\text { Yes } \\
\text { No }\end{array}$ & $\begin{array}{l}21(50.0) \\
52(82.5)\end{array}$ & $\begin{array}{l}21(50.0) \\
11(17.5)\end{array}$ & $(<0.001)$ \\
\hline $\begin{array}{l}\text { Straight away refer } \\
\text { someone with rash } \\
\text { to dermatologist? }\end{array}$ & $\begin{array}{l}\text { Yes } \\
\text { No }\end{array}$ & $\begin{array}{l}46(78.0) \\
27(58.7)\end{array}$ & $\begin{array}{l}13(22.0) \\
19(41.3)\end{array}$ & $(\mathbf{0 . 0 3 3 )}$ \\
\hline $\begin{array}{l}\text { Take scraping for } \\
\text { fungal culture? }\end{array}$ & $\begin{array}{l}\text { Yes } \\
\text { No }\end{array}$ & $\begin{array}{l}3(42.9) \\
70(71.4)\end{array}$ & $\begin{array}{l}4(57.1) \\
28(28.6)\end{array}$ & $(0.125)^{*}$ \\
\hline $\begin{array}{l}\text { Take } \\
\text { biopsy? }\end{array}$ & $\begin{array}{l}\text { Yes } \\
\text { No }\end{array}$ & $\begin{array}{l}2(50.0) \\
71(70.3)\end{array}$ & $\begin{array}{l}2(50.0) \\
30(29.7)\end{array}$ & $(0.356)^{*}$ \\
\hline $\begin{array}{l}\text { Know how much } \\
\text { cream is needed to } \\
\text { cover the body? }\end{array}$ & $\begin{array}{l}\text { Yes } \\
\text { No }\end{array}$ & $\begin{array}{l}3(25.0) \\
70(75.3)\end{array}$ & $\begin{array}{l}9(75.0) \\
23(24.7)\end{array}$ & $(0.001)^{*}$ \\
\hline
\end{tabular}

Table 7: Association between physicians` practice in dermatology and their knowledge about common dermatological problems. (*Fisher exact test)

Almost half of male physicians (46.4\%) compared to $27.8 \%$ of female physicians reported looking at the feet of the patient who has rash on the hand. This difference in practice between male and female physicians was borderline statistically significant, $\mathrm{p}=0.050$ as illustrated in table 8 .

\begin{tabular}{|l|l|l|l|}
\hline & \multicolumn{2}{|l|}{ Physician`s gender } & p- \\
\cline { 2 - 3 } & $\begin{array}{l}\text { Female } \\
\text { N=36 } \\
\mathbf{N}(\%)\end{array}$ & $\begin{array}{l}\text { Male } \\
\text { N=69 } \\
\text { N (\%) }\end{array}$ & e \\
\hline $\begin{array}{l}\text { Look at the feet of } \\
\text { the person who has } \\
\text { rash on the hand }\end{array}$ & $10(27.8)$ & $32(46.4)$ & \\
$\begin{array}{l}\text { Yes } \\
\text { No }\end{array}$ & $26(72.2)$ & $37(53.6)$ & $\begin{array}{l}\mathbf{0 . 0 5} \\
\mathbf{0}\end{array}$ \\
\hline
\end{tabular}

Table 8: The management of skin disorders that associated with their gender.

From table 9, it is evident that all of non-Saudi physicians compared to $79.1 \%$ of Saudi physicians reported treating of patients with dermatitis. This difference was statistically significant, $\mathrm{p}<0.001$. Most of nonSaudi physicians $(82.3 \%$ ) compared to only $39.5 \%$ of Saudi physicians advised their patients with dermatitis about diet. This difference was statistically significant, $\mathrm{p}<0.001$. Contrary to the above results, more than half of Saudi physicians $(53.5 \%$ ) compared to $30.6 \%$ of non-Saudi physicians reported looking at the feet of the person who had rash on the hand. This difference was borderline statistically significant, $\mathrm{p}=0.019$. Similarly, more Saudi physicians compared to non-Saudis (18.6\% versus $6.5 \%$ ) knew how much cream is needed to cover the body. The difference was borderline statistically significant, 0.054

\begin{tabular}{|l|l|l|l|}
\hline & \multicolumn{2}{|l|}{ Physician`s nationality } & p-value \\
\cline { 2 - 4 } & $\begin{array}{l}\text { Saudi } \\
\mathbf{N = 4 3} \\
\mathbf{N}(\%)\end{array}$ & $\begin{array}{l}\text { Non-Saudi } \\
\mathbf{N = 6 2} \\
\mathbf{N}(\%)\end{array}$ & \\
\hline Treat the patient with dermatitis & $34(79.1)$ & $62(100)$ & \\
Yes & $9(20.9)$ & $0(0.0)$ & $<\mathbf{0 . 0 0 1}$ \\
No & & & \\
\hline $\begin{array}{l}\text { Advice the patient with dermatitis } \\
\text { about diet }\end{array}$ & $17(39.5)$ & $51(82.3)$ & \\
Yes & $26(60.5)$ & $11(17.7)$ & $<\mathbf{0 . 0 0 1}$ \\
No & & & \\
\hline
\end{tabular}




\begin{tabular}{|l|l|l|l|}
\hline $\begin{array}{l}\text { Look at the feet of the person who } \\
\text { has rash on the hand }\end{array}$ & & & \\
Yes & $23(53.5)$ & $19(30.6)$ & \\
No & $20(46.5)$ & $43(69.4)$ & $\mathbf{0 . 0 1 9}$ \\
\hline Know how much cream is needed to & & & \\
cover the body & & & \\
Yes & $8(18.6)$ & $4(6.5)$ & \\
No & $35(81.4)$ & $58(93.5)$ & $\mathbf{0 . 0 5 4}$ \\
\hline
\end{tabular}

Table 9: The management of skin disorders that associated with their nationality.

As shown in table 10, 68.7\% of higher than Bachelor educated physicians compared to $42.7 \%$ of those with bachelor degree reported advising their patients with acne about diet. The difference was borderline statistically significant, 0.054 .More than half $(59.6 \%)$ of physician with bachelor compared to 31.3 of those with higher qualification thought that stress is the most important factor for in the aetiology of dermatitis, psoriasis and acne. The difference was statistically significant, 0.036.Most of physicians with higher qualification (81.3\%) compared to $29.2 \%$ of those with bachelor reported looking at the feet of the person who has rash on the groin. The difference was statistically significant, $\mathrm{p}<0.001$. Similarly, most of physicians with higher qualification $(81.3 \%$ ) compared to $32.6 \%$ of those with bachelor reported looking at the feet of the person who has rash on the hand. The difference was statistically significant, $\mathrm{p}<0.0001$. Almost two-thirds of physicians with bachelor $(60.7 \%)$ compared to $31.3 \%$ of those with higher degrees reported straight away referring of patients with rash to dermatologist. The difference was statistically significant, $p=0.029$. One eighth $(12.5 \%)$ of physicians with high qualification compared $5.6 \%$ of those with bachelor reported taking of scraping for fungal culture. The difference was not statistically significant, $\mathrm{p}=0.310$.

\begin{tabular}{|c|c|c|c|}
\hline & \multicolumn{2}{|c|}{$\begin{array}{l}\text { Physician`s } \\
\text { education }\end{array}$} & \multirow[t]{2}{*}{ p-value } \\
\hline & $\begin{array}{l}\text { MBBS } \\
\mathbf{N}=89 \\
\mathrm{~N}(\%)\end{array}$ & $\begin{array}{l}\text { Higher } \\
\mathrm{N}=16 \\
\mathrm{~N}(\%)\end{array}$ & \\
\hline $\begin{array}{l}\text { Advice the patient with acne } \\
\text { about diet } \\
\text { Yes } \\
\text { No }\end{array}$ & $\begin{array}{l}38(42.7) \\
51(57.3)\end{array}$ & $\begin{array}{l}11(68.7) \\
5(31.3)\end{array}$ & 0.054 \\
\hline $\begin{array}{l}\text { Think that stress is the most } \\
\text { important factor for in the } \\
\text { aetiology of dermatitis, Psoriasis } \\
\text { and acne } \\
\text { Yes } \\
\text { No }\end{array}$ & $\begin{array}{l}53(59.6) \\
36(40.4)\end{array}$ & $\begin{array}{l}5(31.3) \\
11(68.7)\end{array}$ & 0.036 \\
\hline $\begin{array}{l}\text { Look at the feet of the person } \\
\text { who has rash on the groin } \\
\text { Yes } \\
\text { No }\end{array}$ & $\begin{array}{l}26(29.2) \\
63(70.8)\end{array}$ & $\begin{array}{l}13(81.3) \\
3(18.7)\end{array}$ & $<0.001$ \\
\hline $\begin{array}{l}\text { Look at the feet of the person } \\
\text { who has rash on the hand } \\
\text { Yes } \\
\text { No }\end{array}$ & $\begin{array}{l}29(32.6) \\
60(67.4)\end{array}$ & $\begin{array}{l}13(81.3) \\
3(18.7)\end{array}$ & $<0.001$ \\
\hline $\begin{array}{l}\text { Straight away refer someone } \\
\text { with rash to dermatologist } \\
\text { Yes } \\
\text { No }\end{array}$ & $\begin{array}{l}54(60.7) \\
35(39.3) \\
\end{array}$ & $\begin{array}{l}5(31.3) \\
11(68.7) \\
\end{array}$ & 0.029 \\
\hline
\end{tabular}




\begin{tabular}{|l|l|l|l|}
\hline Take scraping for fungal culture & & & \\
Yes & $5(5.6)$ & $2(12.5)$ & \\
No & $84(94.4)$ & $14(87.5)$ & $\mathbf{0 . 3 1 0}$ \\
\hline
\end{tabular}

Table 10: The management of skin disorders that associated with their education.

As demonstrated in table 11, 61\% of family physicians (FPs) compared to $37.5 \%$ of GPs reported advising their patients with acne about diet. The difference was statistically significant, 0.019.Most of GPs (75\%) compared to $48.8 \%$ of family physicians reported advising their patients with dermatitis about diet. The difference was statistically significant, 0.006 . More than half of FPs $(56.1 \%)$ compared to $25 \%$ of GPs reported looking at the feet of the person who has rash on the groin. The difference was statistically significant, $\mathrm{p}=0.001$. Almost twothirds of FPs (65.9\%) compared to $23.4 \%$ of GPs reported looking at the feet of the person who has rash on the hand. The difference was statistically significant, $\mathrm{p}<0.001$. Less than half of FPs $(46.3 \%)$ compared to $62.5 \%$ of GPs reported straight away referring of patients with rash to dermatologist. The difference was not statistically significant, $\mathrm{p}=0.104$. Almost a quarter of FPs (22\%) compared to $4.7 \%$ of GPs knew how much cream is needed to cover the body. The difference was statistically significant, $\mathrm{p}=0.007$.

\begin{tabular}{|c|c|c|c|}
\hline & \multicolumn{2}{|c|}{$\begin{array}{l}\text { Physician`s } \\
\text { profession }\end{array}$} & \multirow[t]{2}{*}{ p-value } \\
\hline & $\begin{array}{l}\text { GP } \\
N=64 \\
N(\%)\end{array}$ & $\begin{array}{l}\text { FPs } \\
N=41 \\
N(\%)\end{array}$ & \\
\hline $\begin{array}{l}\text { Advice the patient with } \\
\text { acne about diet } \\
\text { Yes } \\
\text { No }\end{array}$ & $\begin{array}{l}24(37.5) \\
40(62.5)\end{array}$ & $\begin{array}{l}25(61.0) \\
16(39.0)\end{array}$ & 0.019 \\
\hline $\begin{array}{l}\text { Advice the patient with } \\
\text { dermatitis about diet } \\
\text { Yes } \\
\text { No }\end{array}$ & $\begin{array}{l}48(75.0) \\
16(25.0)\end{array}$ & $\begin{array}{l}20(48.8) \\
21(51.2)\end{array}$ & 0.006 \\
\hline $\begin{array}{l}\text { Look at the feet of the } \\
\text { person who has rash on } \\
\text { the groin } \\
\text { Yes } \\
\text { No }\end{array}$ & $\begin{array}{l}16(25.0) \\
48(75.0)\end{array}$ & $\begin{array}{l}23(56.1) \\
18(43.9)\end{array}$ & 0.001 \\
\hline $\begin{array}{l}\text { Look at the feet of the } \\
\text { person who has rash on } \\
\text { the hand } \\
\text { Yes } \\
\text { No }\end{array}$ & $\begin{array}{l}15(23.4) \\
49(76.6)\end{array}$ & $\begin{array}{l}27(65.9) \\
14(34.1)\end{array}$ & $<0.001$ \\
\hline $\begin{array}{l}\text { Straight away } \begin{array}{r}\text { refer } \\
\text { someone with rash to } \\
\text { dermatologist }\end{array} \\
\text { Yes } \\
\text { No } \\
\end{array}$ & $\begin{array}{l}40(62.5) \\
24(37.5)\end{array}$ & $\begin{array}{l}19(46.3) \\
22(53.7)\end{array}$ & 0.104 \\
\hline $\begin{array}{l}\text { Know how much cream is } \\
\text { needed to cover the body } \\
\text { Yes } \\
\text { No }\end{array}$ & $\begin{array}{l}3(4.7) \\
61(95.3)\end{array}$ & $\begin{array}{l}9(22.0) \\
32(78.0)\end{array}$ & 0.007 \\
\hline
\end{tabular}

Table 11: Significant physicians` practices in the management of skin disorders that associated with their profession. 
Number of patients managed by PHC physicians ranged between two and 80 patients. More than half of them $(55.2 \%)$ managed more than 40 patients daily as seen in figure 2. Figure 3 shows that educational activities in dermatology at PHCC were reported by $15.2 \%$ of the respondents whereas $9.2 \%$ and $4.8 \%$ of them reported presence of data or registers for dermatological cases and guideline for management of dermatological disorders, respectively. Almost a third of the respondents $(31.4 \%)$ managed more than 10 years dermatological patients. Figure 4Regarding health services that are provided to dermatological patients in PHCCs, prescribing drugs $(90.5 \%)$ and referring $(84.8 \%)$ were the most common reported services while hygiene or dietary counseling were reported by half of the respondents. Screening was reported by only $3.8 \%$ of them. Figure 5

Almost half of the PHC providers $(49.5 \%)$ were incompetent to manage patients with skin disorders and only $4.8 \%$ were very competent (Figure 6). Among those who are incompetent, lack of knowledge was reported by $92.3 \%$ of them whereas lack of skills and negative attitude were reported by $71.2 \%$ and $32.7 \%$ of them as illustrated in figure 7.Almost a third of the PHC physicians in Abha (30.2\%) reported attendance to any training courses in dermatology at their PHCCs as shown in figure 8. These courses were either in the form of lectures $(69 \%)$, workshop $(17.2 \%)$ or symposium $(37.9 \%)$ as demonstrated in figure 9.

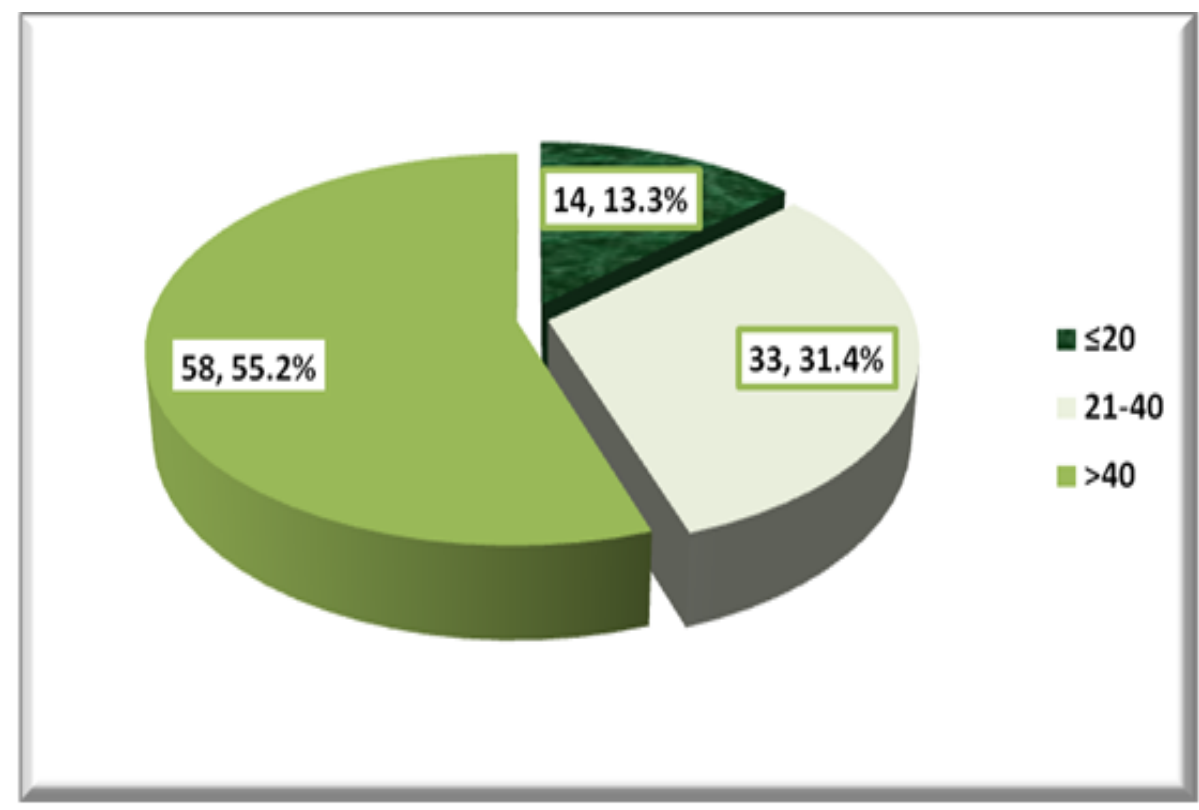

Figure 2: Number of patients managend by participants per day.

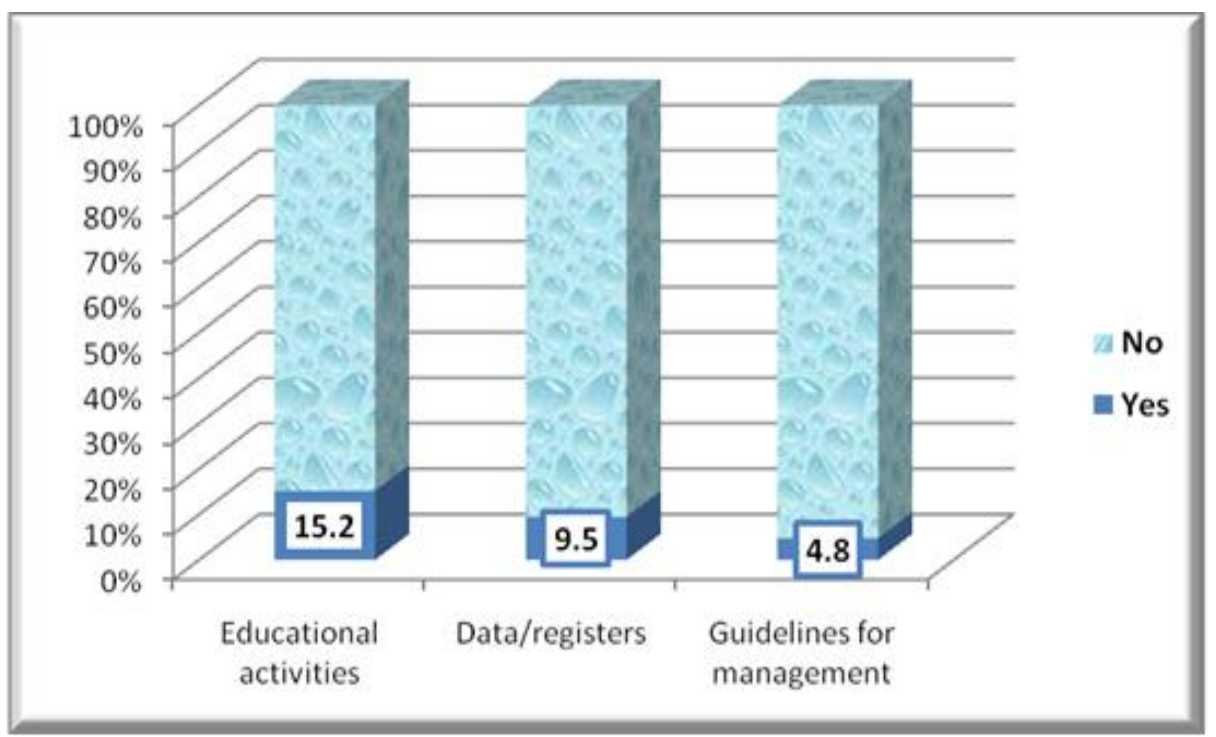

Figure 3: Dermatology-related activities at PHCCs. 


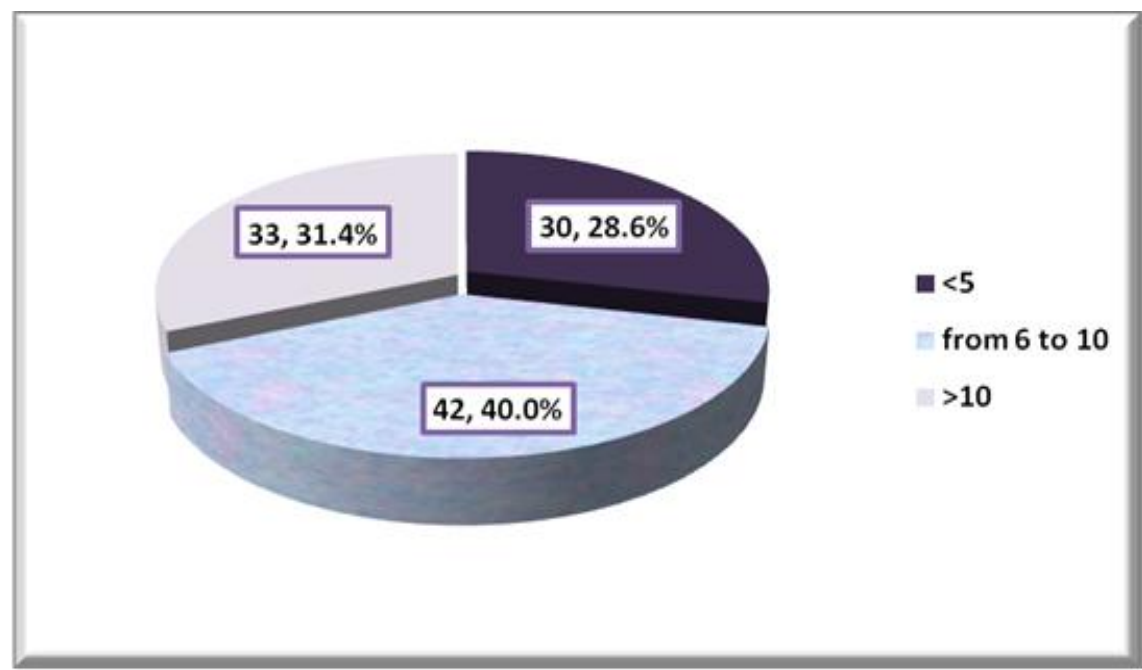

Figure 4: Number of dermatological patients managed by participants per day.

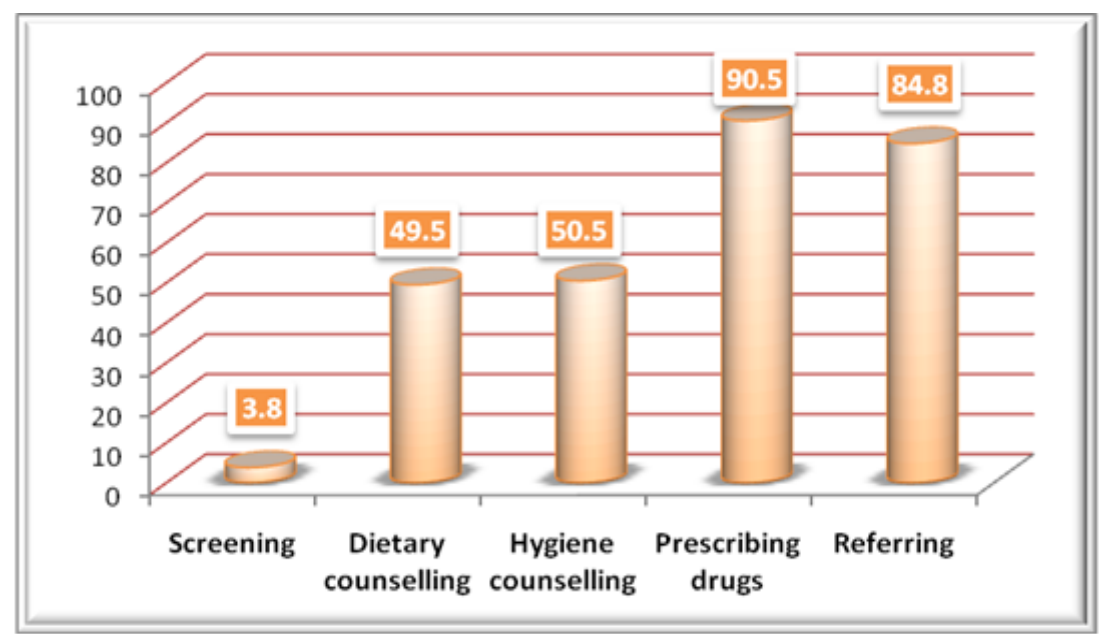

Figure 5: Health services that are provided to dermatological patients in PHCCs.

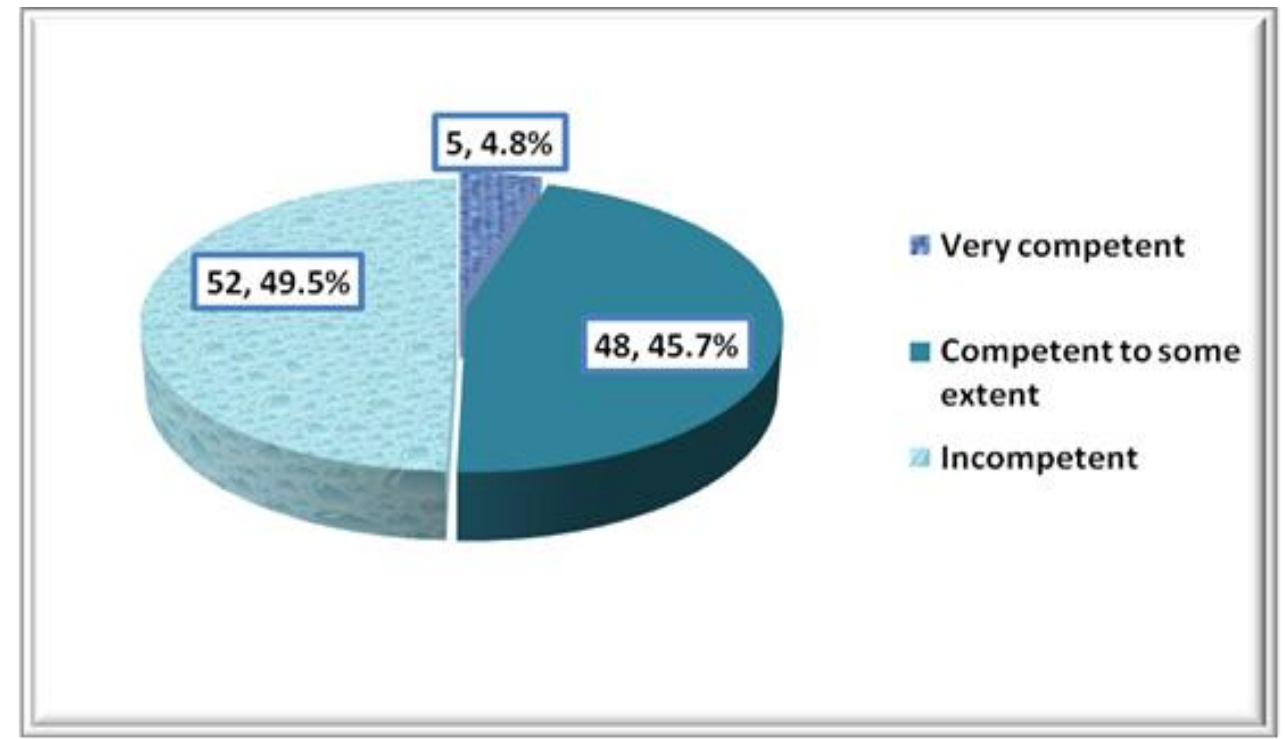

Figure 6: Competence of PHC physicians to manage patient with skin disorders. 


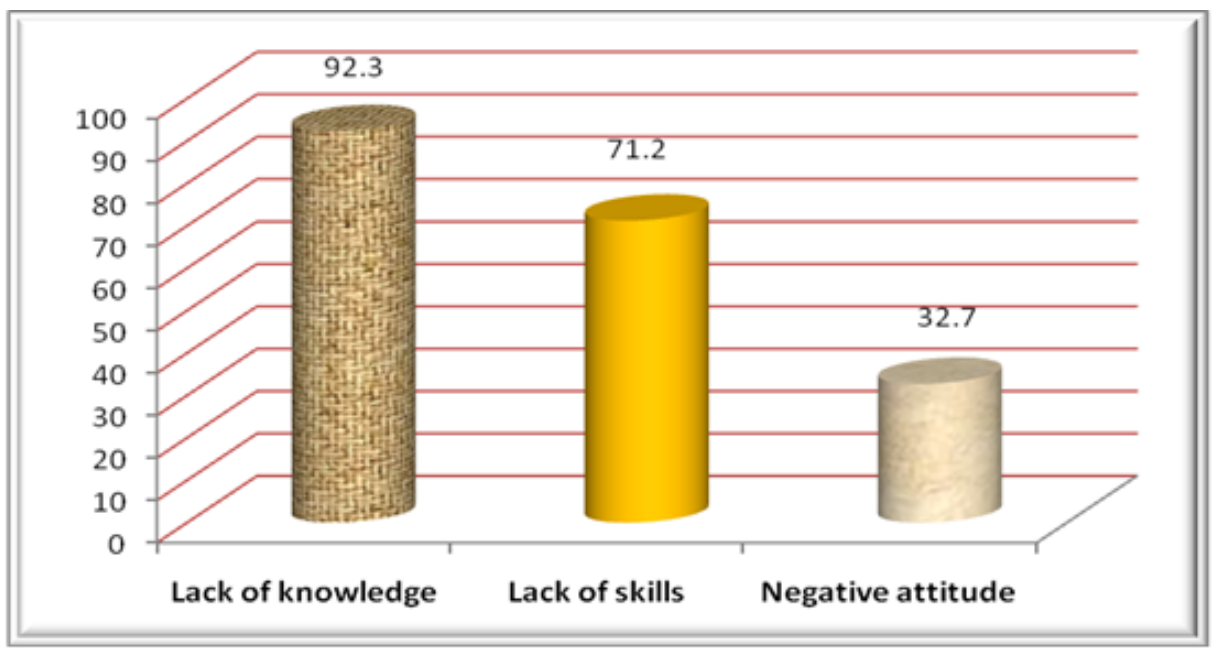

Figure 7: Reasons for PHC physicians for being non-competent in managing patients with dermatological disorders.

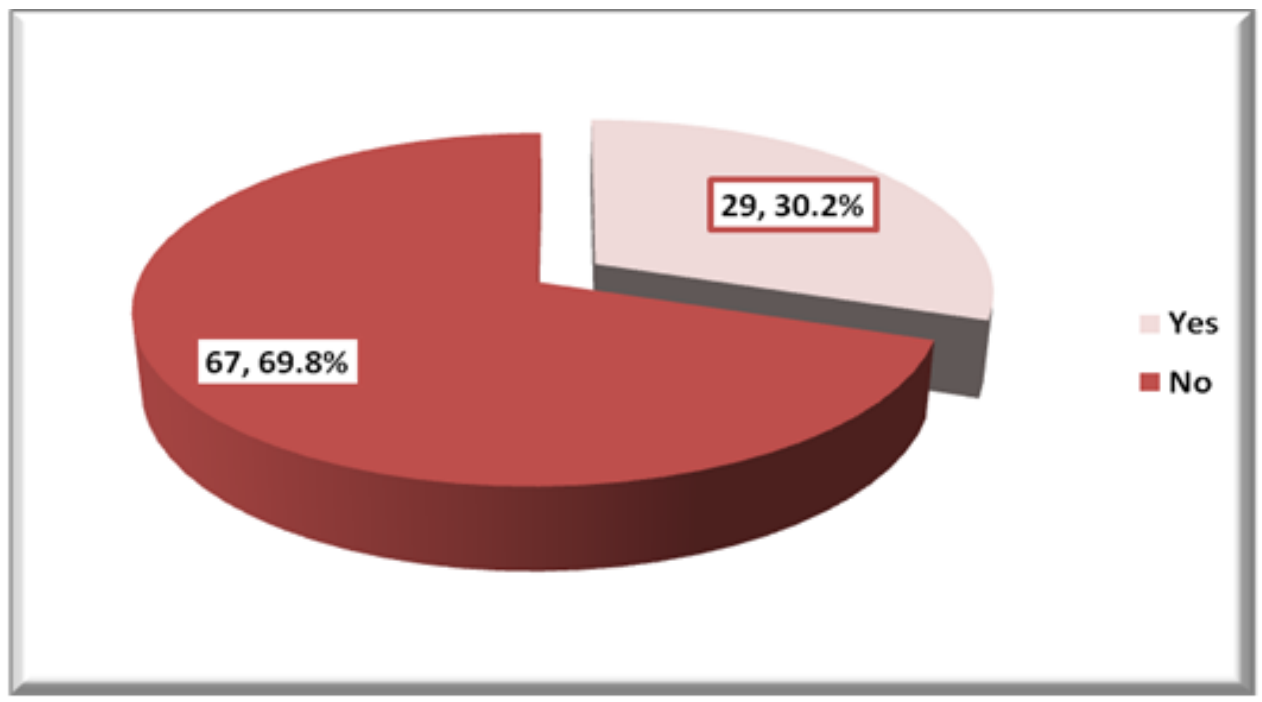

Figure 8: History of attending any training course on dermatology among PHC physicians in Abha.

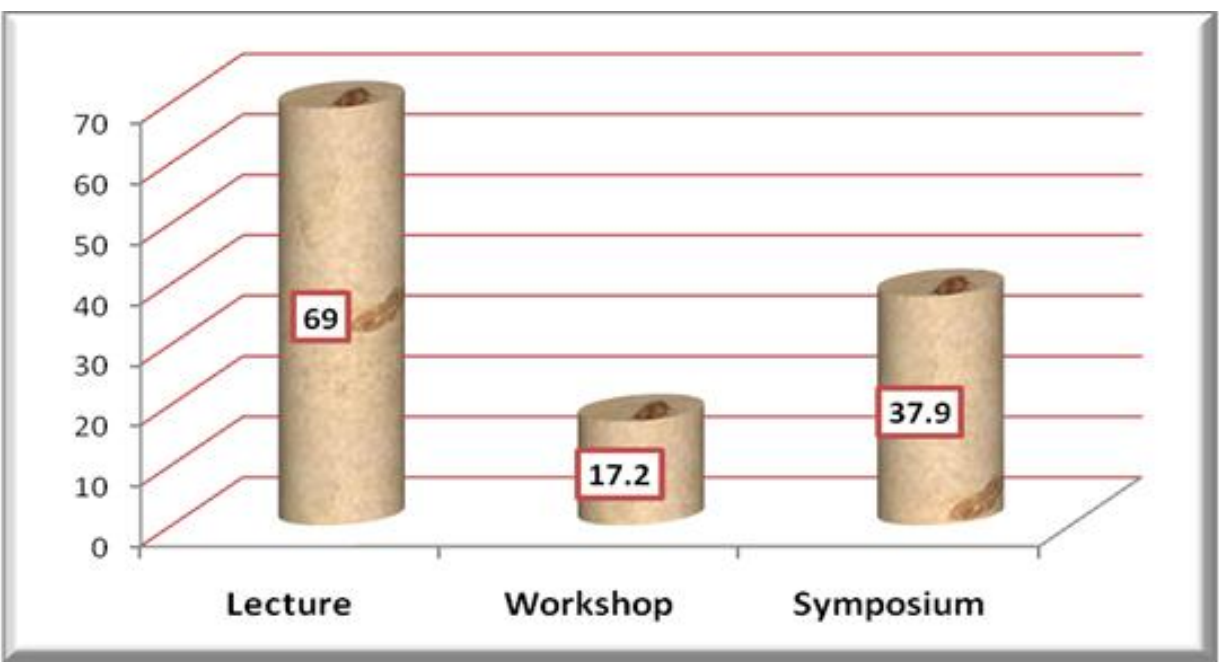

Figure 9: Type of training course in dermatology reported by PHC physicians in Abha $(n=29)$ From table 12, it is evident that almost a third of primary healthcare providers are very confident in managing acne $(32.4 \%)$ and eczema $(31.4 \%)$ whereas only $13.3 \%, 11.4 \%$ and $10.5 \%$ were very confident in managing 
fungal diseases, warts and rosacea, respectively. Noneof them are very confident in managing leg ulcer and skin cancer. Majority of them $(91.4 \%)$ reported that they need to learn in management of skin cancer while almost two thirds of them reported that they need to learn a lot in management of angio-oedema (62.9\%) and slightly more than half of them $(51.04 \%)$ reported that they need to learn a lot in the management of leg ulcers. As shown in table 13, physicians who were confident in managing psoriasis were more knowledgeable about the management of common dermatological problems than those who reported that they need to learn $(43.7 \%$ versus $24.7 \%$ ). This difference was statistically significant, $\mathrm{p}=0.049$. Physicians who were confident in managing warts were more knowledgeable about the management of common dermatological problems than those who reported that they need to learn $(43.6 \%$ versus $22.7 \%)$. This difference was statistically significant, $\mathrm{p}=0.049$. Similarly, physicians who were confident in managing infestations were more knowledgeable about the management of common dermatological problems than those who reported that they need to learn $(47.1 \%$ versus $22.5 \%$ ). This difference was statistically significant, $\mathrm{p}=0.011$. Also table 13 shows that physicians who were confident in managing fungal diseases were more knowledgeable about the management of common dermatological problems than those who reported that they need to learn (35.4\% versus $15.4 \%)$. This difference was statistically significant, $\mathrm{p}=0.042$. Physicians who are confident in managing leg ulcers were more knowledgeable about the management of common dermatological problems than those who reported that they need to learn $(58.8 \%$ versus $25.0 \%)$. This difference was statistically significant, $\mathrm{p}=0.006$. Physicians who are confident in managing angio-oedema were more knowledgeable about the management of common dermatological problems than those who reported that they need to learn $(72.7 \%$ versus $19.3 \%)$. This difference was statistically significant, $\mathrm{p}<0.001$. Finally, physicians who are confident in managing rosacea were more knowledgeable about the management of common dermatological problems than those who reported that they need to learn $(73.3 \%$ versus $23.3 \%$ ). This difference was statistically significant, $p<0.001$.

\begin{tabular}{|c|c|c|c|c|}
\hline & $\begin{array}{l}\text { Very } \\
\text { confident } \\
\text { N }(\%)\end{array}$ & $\begin{array}{l}\text { Quit } \\
\text { confident } \\
\text { N }(\%)\end{array}$ & $\begin{array}{l}\text { Need to } \\
\text { learn a bit } \\
\mathrm{N}(\%)\end{array}$ & $\begin{array}{l}\text { Need to } \\
\text { learn a lot } \\
\mathrm{N}(\%)\end{array}$ \\
\hline Acne & $34(32.4)$ & $50(47.6)$ & $20(19.0)$ & $1(1.0)$ \\
\hline Eczema & $33(31.4)$ & $48(45.7)$ & $19(18.1)$ & $5(4.8)$ \\
\hline Psoriasis & $9(8.6)$ & $23(21.9)$ & $40(38.1)$ & $33(31.4)$ \\
\hline Warts & $12(11.4)$ & $27(25.7)$ & $39(37.1)$ & $27(25.7)$ \\
\hline Infestations & $11(10.5)$ & $23(21.9)$ & $34(32.4)$ & $37(35.2)$ \\
\hline Fungal diseases & $14(13.3)$ & $65(61.9)$ & $14(13.3)$ & $12(11.4)$ \\
\hline Leg ulcers & $\mathbf{0}(\mathbf{0 . 0})$ & $17(16.2)$ & $34(32.4)$ & $54(51.4)$ \\
\hline Skin cancer & $\mathbf{0}(\mathbf{0 . 0})$ & $4(3.8)$ & $5(4.8)$ & $96(91.4)$ \\
\hline Angio-oedema & $3(2.9)$ & $19(18.1)$ & $17(16.2)$ & $66(62.9)$ \\
\hline Rosacea & $11(10.5)$ & $4(3.8)$ & $20(19.0)$ & $70(66.7)$ \\
\hline
\end{tabular}

Table 12: Confidentiality of primary healthcare physicians to manage common dermatological disorders

\begin{tabular}{|c|c|c|c|c|}
\hline & & \multicolumn{2}{|c|}{$\begin{array}{l}\text { Knowledge of common } \\
\text { dermatological problems }\end{array}$} & \multirow{2}{*}{$\begin{array}{l}\text { Chi-square } \\
\text { value } \\
\text { (p-value) }\end{array}$} \\
\hline & & $\begin{array}{l}\text { Insufficient } \\
\mathbf{N}=73 \\
\mathbf{N}(\%)\end{array}$ & $\begin{array}{l}\text { Sufficient } \\
\mathbf{N}=32 \\
\mathrm{~N}(\%)\end{array}$ & \\
\hline Acne & $\begin{array}{l}\text { Confident (84) } \\
\text { Need to learn (21) }\end{array}$ & $\begin{array}{l}55(65.6) \\
18(85.7) \\
\end{array}$ & $\begin{array}{l}29(34.5) \\
3(14.3) \\
\end{array}$ & $(0.057)$ \\
\hline Eczema & $\begin{array}{l}\text { Confident (81) } \\
\text { Need to learn (24) }\end{array}$ & $\begin{array}{l}55(67.9) \\
18(75.0) \\
\end{array}$ & $\begin{array}{l}26(32.1) \\
6(25.0) \\
\end{array}$ & $(0.347)$ \\
\hline Psoriasis & $\begin{array}{l}\text { Confident (32) } \\
\text { Need to learn (73) }\end{array}$ & $\begin{array}{l}18(56.3) \\
55(75.3) \\
\end{array}$ & $\begin{array}{l}14(43.7) \\
18(24.7) \\
\end{array}$ & $(0.049)$ \\
\hline Warts & $\begin{array}{l}\text { Confident (39) } \\
\text { Need to learn (66) }\end{array}$ & $\begin{array}{l}22(56.4) \\
51(77.3)\end{array}$ & $\begin{array}{l}17(43.6) \\
15(22.7)\end{array}$ & $(0.025)$ \\
\hline
\end{tabular}




\begin{tabular}{|c|c|c|c|c|}
\hline Infestations & $\begin{array}{l}\text { Confident (34) } \\
\text { Need to learn (71) }\end{array}$ & $\begin{array}{l}18(52.9) \\
55(77.5)\end{array}$ & $\begin{array}{l}16(47.1) \\
16(22.5)\end{array}$ & $(0.011)$ \\
\hline Fungal diseases & $\begin{array}{l}\text { Confident (79) } \\
\text { Need to learn (26) }\end{array}$ & $\begin{array}{l}51(64.6) \\
22(84.6)\end{array}$ & $\begin{array}{l}28(35.4) \\
4(15.4)\end{array}$ & $(0.042)$ \\
\hline Leg ulcers & $\begin{array}{l}\text { Confident (17) } \\
\text { Need to learn (88) }\end{array}$ & $\begin{array}{l}7(41.2) \\
66(75.0)\end{array}$ & $\begin{array}{l}10(58.8) \\
22(25.0)\end{array}$ & $(0.006)$ \\
\hline Skin cancer & \begin{tabular}{l}
\multicolumn{2}{l}{ Confident (4) } \\
Need to learn \\
$(101)$
\end{tabular} & $\begin{array}{l}2(50.0) \\
71(70.3)\end{array}$ & $\begin{array}{l}2(50.0) \\
30(29.7)\end{array}$ & $(0.356)$ \\
\hline Angio-oedema & $\begin{array}{l}\text { Confident (22) } \\
\text { Need to learn (83) }\end{array}$ & $\begin{array}{l}6(27.3) \\
67(80.7) \\
\end{array}$ & $\begin{array}{l}16(72.7) \\
16(19.3) \\
\end{array}$ & $(<0.001)$ \\
\hline Rosacea & $\begin{array}{l}\text { Confident (15) } \\
\text { Need to learn (90) }\end{array}$ & $\begin{array}{l}4(26.7) \\
69(76.7)\end{array}$ & $\begin{array}{l}11(73.3) \\
21(23.3)\end{array}$ & $(<0.001)$ \\
\hline
\end{tabular}

Table 13: Association between physicians` personal characteristics and their knowledge about common dermatological disorders

Figure 10 demonstrated that $61 \%$ of physicians had good experience in managing skin disorders whereas only $1 \%$ reported excellent experience and $38.1 \%$ had poor experience in managing skin disorders.



Figure 10: Primary health care physicians`expertization in managing skin disorders

Lack of guidelines (86.7\%), lack of training (80\%), lack of educational materials $(66.7 \%)$ and lack of time and place $(64.8 \%)$ were the commonest reported barriers that face PHC physicians` practics regarding management of dermatological disorders. Figure 11By asking of the respondents about their opinion regarding difficulty in management of skin disorders compared to other body disorders, $73.3 \%$ of them answered that it is more difficult whereas only $7.8 \%$ answered that it is easier. Figure 12 


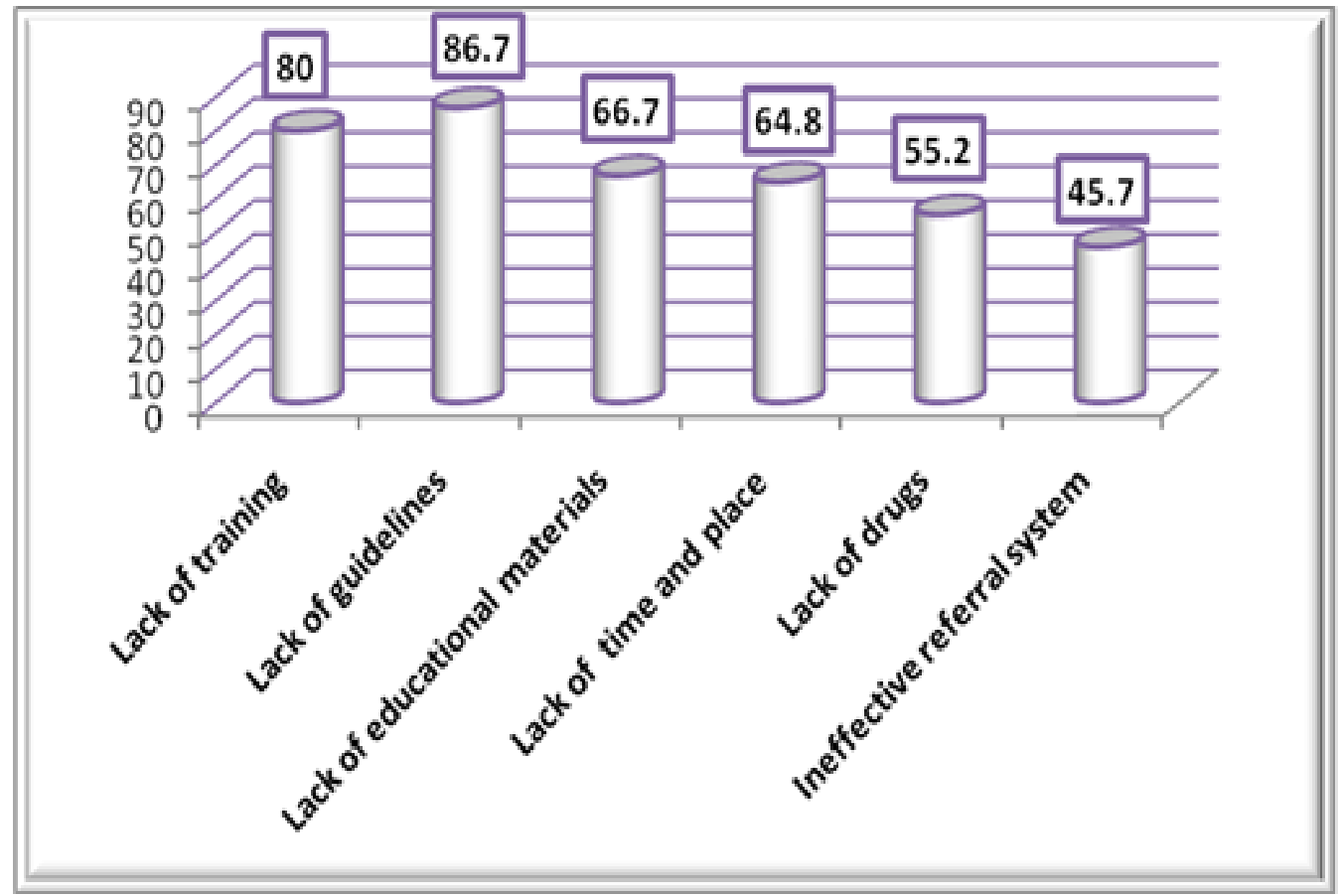

Figure 11: Barriers that face PHC physicians` practics regarding management of dermatological disorders.



Figure 12: Opinion of PHC providers regarding difficulty in management of skin disorders compared to other body disorders.

Responses of the PHC physicians to a question concerning difficulties faced by them in management of skin disorders are summarized in figure 13. Difficulties to arrange for referral, difficulties to communicate, lack of experience, difficulties to give counselling about diet and difficulties to give counselling about general hygiene were reported by $52.4 \%, 41 \%, 40 \%$ and $39 \%$ of them, respectively. 


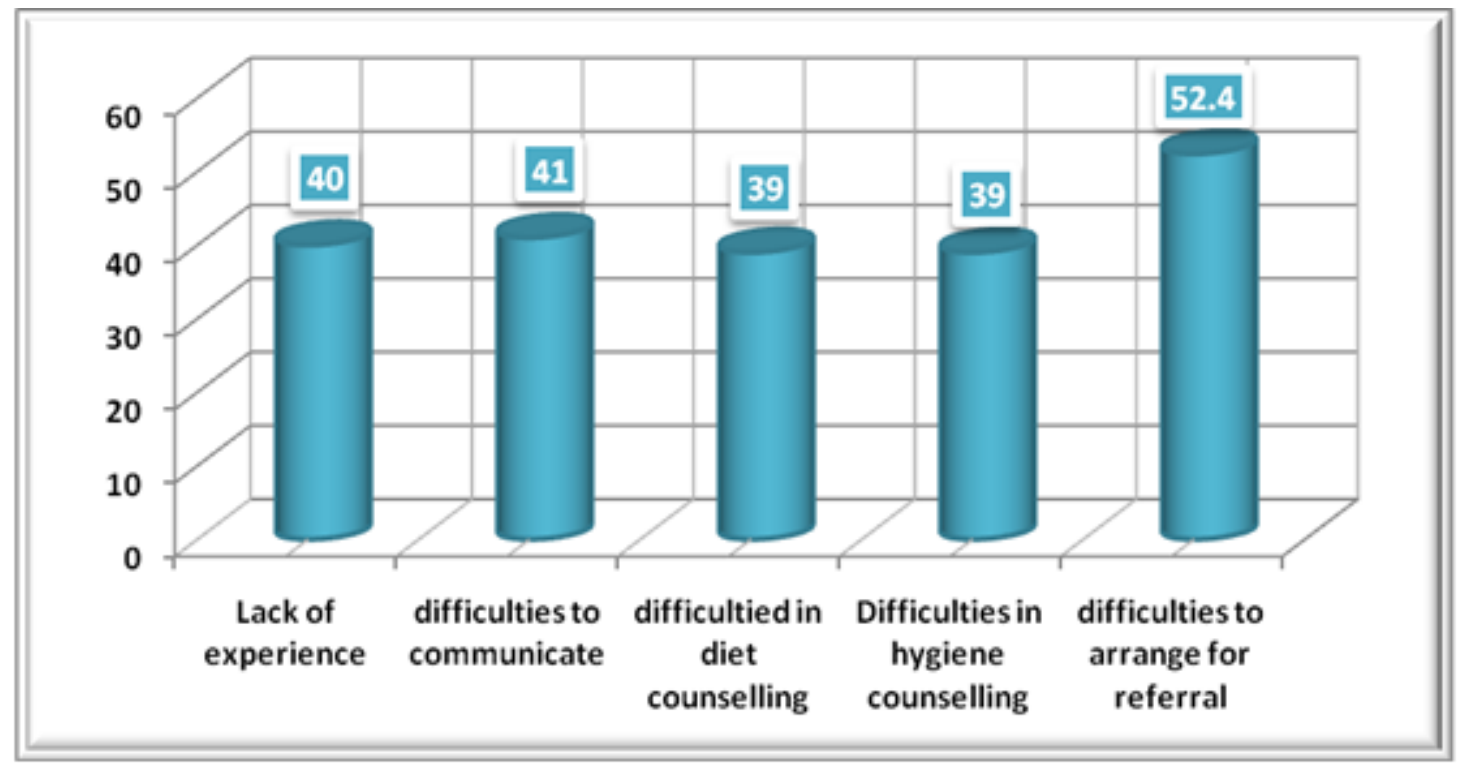

Figure 13: Difficulties faced by PHC providers in management of skin disorders.

\section{DISCUSSION}

Family physicians are on the front line of managing dermatologic conditions. Pattern recognition is extremely important with skin complaints. A thorough history must be taken with attention to environmental, infectious and occupational factors that may irritate the skin. Family physicians must develop keen observational skills and use appropriate terminology to characterize different skin lesions. [31]According to AAFP, a family physician must have knowledge of different diagnoses associated with different lesion types and must know where to access appropriate information in a timely manner using textbook or online resources.[31] In the present study, more than two thirds $(69.5 \%)$ of primary healthcare physicians had insufficient knowledge regarding common dermatological disorders. According to our results, the majority of primary healthcare physicians reported that the management of skin disorders is difficult, if compared with other body disorders. The commonest obstacles reported by them were lack of guidelines, training and educational materials. In a study conducted by Hansra et al in USA, [32] PHC physicians reported that dermatology was not as adequately taught as curricular areas such as asthma and diabetes. Less than $40 \%$ of them felt their medical school curriculum adequately prepared them to diagnose and treat common skin disorders. This may reflected the amount of curricular time devoted to dermatology in comparison to other content areas. This could explain why PHC physicians in our study felt that management of skin disorders is difficult compared to management of other body organs. Family physicians are experts at treating the whole patient and are well suited to detecting systemic disease that may have dermatologic manifestations.[33] According to AAFP,[31] early diagnostic biopsy and definitive surgical or medical treatment are often well within the scope of a family physician's skills. Family physicians must be proficient on a systems level in providing timely, cost-effective and cosmetically excellent skin surgery. Patients should be given realistic expectations on wound healing and warned in advance of possible untoward outcomes. In the current study, only $3.8 \%$ of PHC physicians took punch biopsy in their practice and $6.7 \%$ took scraping for fungal culture. In addition, none of them were very confident in the management of leg ulcer and skin cancer. Furthermore, $51.4 \%$ and $91.4 \%$ of them reported that they need to learn a lot in the management of leg ulcer and skin cancer, respectively. These topics should be prioritized for improvement in dermatology curricula in medical schools.Quite similar to our findings has been reported by others who reported that there were numerous topics that PHC physicians identified as very important in their practices, but they inadequately taught in their medical school dermatology curricula. These include skin infections, leg ulcers/wound care, cutaneous drug eruptions, infestations, and viral exanthems. [32] Most schools teach students about dermatologic procedures, but do not expect students to learn how to perform them.[34] Since many PHC physicians are expected to perform skin biopsies, this procedures should become a part of the medical school or postgraduate dermatology curriculum. As more than $50 \%$ and $90 \%$ of PHC physicians need to learn more in management of leg ulcer and skin cancer, respectively. Therefore, it should ideally be taught in medical school or, at the very least, in all primary care residency training programs. The Association of American Medical Colleges has similarly recommended that these procedures be taught in medical school. [35]Procedural training is especially important for residents planning to practice in medical and dermatological underserved areas. Eighty-seven percent of PHC physicians in Fresno perform skin biopsies compared to $20 \%$ of PHC physicians in San Francisco [32] and 3.8\% in the current study. PHC physicians not 
only need to know how to perform the procedures correctly, but also to whom to send the tissue for evaluation and how to interpret biopsy results. [36]Ramsey and Fox [37] studied "the ability of primary care physicians to diagnose correctly the 20 most common dermatologic diseases" and found "primary care physicians deficient in their ability to recognize common dermatoses." Lichen planus, recognized by 93 percent of the dermatologists, was correctly diagnosed by only 16 percent of the non-dermatologists. Seborrheic dermatitis was correctly diagnosed by only 29 percent of non-dermatologists (vs. 93 percent of dermatologists); atopic dermatitis by 32 percent of non-dermatologists (vs. 97 percent of dermatologists; and pityriasisrosea was correctly recognized by only 44 percent of non-dermatologists (vs. 97 percent of dermatologists). Malignant basal cell carcinoma, correctly recognized by 100 percent of dermatologists, was misdiagnosed by 30 percent of non dermatologists. Seborrheic keratosis was correctly diagnosed by $100 \%$ of dermatologists, but only 33 percent of the nondermatologists. Contrary to that, Merenstein et al [38] demonstrated that most skin conditions diagnosed and managed by family physicians improve. At day $7,84 \%$ of patients who were contacted reported their skin lesions were "better" or "much better." Moreover, patients said they were highly satisfied with their care. Referrals to subspecialists were infrequent. In the present study, more than $56 \%$ of primary health care physicians straight away refer someone with rash to dermatologist, mostly they were general practitioners, lower educated physicians and those over 50 years old. In Mali, after a single day of training, a marked improvement was seen in the management of skin diseases in primary health care centres, according to changes in defined indicators evaluated in samples of general health care workers.[39]The training of general health care workers in the care of skin disease has been identified as a key to tackling the problem; [40, 41] however, the few previous attempts to do so were not evaluated in a systematic manner [41, 42] or proved disappointing. In Kenya, repeated training of itinerant community health care workers did not produce a steady improvement in the success indicator chosen i.e. the prevalence of targeted disorders. [43] In the present study, almost $30 \%$ of the respondents reported attending any training courses in dermatology. The positive results of PHC training in dermatology was attributed to the chosen strategy such as targeteing the quality of care in primary health care centres rather than prevalence in the general population, using a simplified approach to dermatology, which was derived from similar approaches to other health problems, [44, 45] in which they defined a small group of priority diseases and used a specific flowchart adapted to the targeted care level. [46] with the use of a range of visual aids to facilitate assimilation and finally informal talks with health care workers and the high attendance at sessions suggested a high demand for training in skin diseases added to rapid and visible improvements in practice after training.[39]Following a training course, an overall diagnostic agreement between PHC physicians and dermatologists of $65.52 \%$ has been reported. Primary care physicians were found to overdiagnose diseases caused by papillomavirus and the diagnostic sensitivity was very low for diseases such as basal cell carcinoma and seborrheic keratosis. [47] They stressed the importance of training primary care physicians in the field of dermatology, to provide them with the knowledge needed to recognize common skin lesions such as warts and to avoid confusion with benign skin tumors such as soft fibromas and seborrheic keratosis, lesions often incorrectly identified as warts.

Most skin conditions are morphologically distinctive, meaning that with adequate knowledge and clinical expertise, a correct diagnosis can be made in the majority of cases.This study has significant limitations. First, the study was done in a single city. It should be repeated in other cities to test generalizability. Other limitations are the relatively small size of the study population and the limited number of skin conditions involved, some of which are rare, we assesses clinical dermatologic topics. We did not address the basic structure and function of the skin, description of skin lesions, and performing a complete skin examination. We believed these topics were basic areas of knowledge that should always be included in the medical school curriculum.

\section{CONCLUSION}

More than two-thirds of primary health care providers in Abha city had insufficient knowledge regarding management of common skin disorders. Half of PHC physicians were incompetent in managing patients with skin disorders. Lower qualification among physicians and lack of training courses were important indicators for such insufficient knowledge. Heath services that are commonly provided to dermatological patients in PHCCs were prescribing drugs and referral. Thirty percent of PHC physicians attended training courses in dermatology. More than half of the PHC physicians strongly agreed that they should have a role in the managing of common dermatological disorders. The commonly reported barriers for that are lack of guidelines and training in dermatology.

\section{RECOMMENDATIONS}

1.Stress the importance of providing primary care physicians with the knowledge needed to recognize basic skin lesions and to become familiar with the most common skin disorders seen in primary care settings through regular training courses with CME hours. 
2.Further, we recommend that certain dermatologic content areas be included or strengthened in current medical school dermatology curricula.

3.Supplementation of primary health care centers with guidelines in diagnosis and management of common dermatological disorders and encourage physicians to be familiar with them.

4.Further research in other cities, with larger sample size and more number of skin conditions is recommended for generalizability of the results all over the Kingdom.

5.Inclusion of the basic structure and function of the skin, description of skin lesions, and performing a complete skin examination as basic areas of knowledge in the medical school curriculum.

\section{REFERENCES}

[1] Rea JN, Nehouse ML, Halil T. Skin disease in Lambeth: a community study of prevalence and use of medical care. Br J PrevSoc Med. 1976; 30:107-14.

[2] Diepgen TL, Mahler V. The epidemiology of skin cancer, Br J Dermatol. 2002; 146(suppl.):1-6.

[3] Ryan TJ. Disability in dermatology. Br J Hosp Med. 1991;46:33-6.

[4] Fritsch P, Burgdorf W, Murphy G, RING J. Skin diseases in Europe. Eur J Dermatol 2006; 16 (2): 20918

[5] Williams H, Svensson A, Diepgen Th, Naldi L, Coenraads PJ, Elsner P, et al. Epidemiology of skin diseases in Europe. European Journal of Dermatology. 2006; 16(2):209-14,

[6] Williams HC. Dermatology. In: Stevens A, Raftery J (eds). Health Care Needs Assessment, second series. Oxford: Radcliffe Medical Press, 1997.

[7] Lowell BA, Froelich CW, Federman DG, Kirsner RS. Dermatology in primary care: Prevalence and patient disposition. Journal of the American Academy of Dermatology; 2001: 45(2):250-255.

[8] Johnson M-LT. Skin conditions and related need for medical care among persons aged 1-74 years, United States, 1971-74. Vital and Health Statistics: Series 11, No. 212. DHEW publication No. (PHS) 791660. National Center for Health Statistics 1978:1-72.

[9] Disease in Europe. In: Fritsch P (ed.). White Book Dermatology and Venereology in Europe. Bern: European Dermatology Forum, 2001.

[10] Yousuf MS. The treatment of skin problems in Saudi Arabia Wounds International 2010; 1(4)

[11] Al Shobaili HA. The pattern of skin diseases in the Qassim region of Saudi Arabia: What the primary care physician should know. Ann Saudi Med 2010 Nov; 30(6): 448-53.

[12] Al-Zoman AY, Al-Asmar AK. Pattern of skin diseases at Riyadh Military Hospital. Egyptian Dermatology Online Journal 2008 Dec;4 (2): 1-10

[13] National Institute of Health. Skin Health and Skin Diseases. NIH Medline plus. 2008 fall; 3(4):22-25.

[14] Everyday Health Care: A Consumer Study of Self- medication in Great Britain. London: British Market Research Bureau, 1987.

[15] Royal College of General Practitioners Curriculum 2010, Statement 3.21 Care of People with Skin Problems, revised 30 May 2012.

[16] Ramsay DL, Weary PE. Primary care in dermatology: whose role should it be? J Am AcadDermatol 1996; 35(6):1005-8.

[17] Kirsner RS, Federman DG. Lack of correlation between internists' ability in dermatology and their patterns of treating patients with skin disease. Arch Dermatol 1996; 132(9):1043-6.

[18] Gervert B, Maurer T, Berger T, Pantilat S, McPhee SJ, Wolff M, et al. Primary care physicians as gatekeepers in managed care. Primary care physicians' and dermatologists' skills at secondary prevention of skin cancer. Arch Dermatol 1996;132(9):1030-8.

[19] Johnson MT. On teaching dermatology to non-dermatologists. Arch Dermatol 1994; 130:850-2.

[20] Feldman SR, Fleischer AB, Chen JG. The gatekeeper model is inefficient for the delivery of dermatologic services. J Am AcadDermatol 1999; 40(3):426-32.

[21] Farah Awadalla, Daryl A. Rosenbaum and Fabian Camacho. Dermatologic Disease in Family Medicine. Fam Med 2008; 40(7):507-11.

[22] Williams HC. Epidemiology of skin diseases. In: Champion RH, Burton JL, Burns DA, Breathnach SM (eds). Textbook of Dermatology, 6th edn. Oxford: Blackwell Science, 1998; 139-57.

[23] Diepgen TL, Coenraads PJ. Inflammatory skin disease II: contact dermatitis. In: Williams HC, Strachan DP (eds). The Challange of Dermato-Epidemiology. Boca Raton: CRC Press, 1997; 141-57.

[24] Bahamdan KA, Egere JU. The pattern of skin diseases in Asir region, Saudi Arabia: a 12-month prospective study in a referral hospital. Ann Saudi Med 1995; 15: 455-457.

[25] Shelleh HH, Al-Hatiti HS. Pattern of skin diseases in ahospital in Southwestern Saudi Arabia. Saudi Med J 2004;25: 507-510.

[26] Federman DG, Kirsner RS. The primary care physician and the treatment of patients with skin disorders. DermatolClin 2000;18:215-221, viii. 
[27] Federman DG, Concato J, Kirsner RS. Comparison of dermatologic diagnoses by primary care practitioners and dermatologists. A review of the literature. Arch Fam Med 1999; 8:170-172.

[28] Al-Hoqail IA, Gad A, Crawford RI. Dermatology practice in primary health care services: where do we stand in the Middle East?. International journal of dermatology 2002 Jan; 41(1): 4-7.

[29] Hussein M. Alwadie. Pollen concentration in the atmosphere of Abha city, Saudi Arabia and its relationship with meteorological parameters. Asian Network for Scientific Information. Journal of Applied Sciences 2008; 8:842-847.

[30] Görgülü, I. Metin, C. Mutlu, S. Elmas and E. Uzunali. Evaluation of the questionnaires directed at the dermatologic knowledge level of students at trakyaunivestitykirklareli and edirne health college. Acta MedicaBulgarica. 2008; xxxv (1); 83-93.

[31] American Academy of Family Physicians. Conditions of the skin. AAFP, Reprint No. 271, 2008.

[32] Hansra NK, O’Sullivan P, Cynthia L. Chen CL, Berger TG. Medical school dermatology curriculum: Are we adequately preparing primary care physicians? J Am AcadDermatol 2008; 61:23-9.

[33] Wolff K, Goldsmith LA, Katz SI, Gilchrest BA, Paller A, Leffell DJ. Fitzpatrick's Dermatology in General Medicine. 7th ed. New York, N.Y.: McGraw-Hill Professional, 2008.

[34] McClesky P, Gilson R, Devillez R. Medical student core curriculum in dermatology. Chicago: Dermatology Teachers Exchange Group; 2007.

[35] The AAMC project on the clinical education of medical students: clinical skills education. 2005.

[36] Laidlaw T, MacLeod H, Kaufman D, Langille D, Sargeant J. Implementing a communication skills programme in medical school: needs assessment and programme change. Med Educ 2002;36:115-24.

[37] Awadalla F; Rosenbaum DA, Camacho F, Fleischer AB, Feldman SR. Dermatologic Disease in Family Medicine. Family Medicine 2008; 40(7):507-511

[38] Merenstein D, Meyers D, Krist A, Jessica D, Stephen M, Robert P, et al. How well do family physicians manage skin lesions? The Journal of Family Practice 2007;56(1):40-45

[39] Mahé A, Faye O, N'Diaye HT, Konaré HD, Coulibaly I, Kéita S, et al. Integration of basic dermatological care into primary health care services in Mali. Bulletin of the World Health Organization 2005; 83:935-941.

[40] Chen SC, Bayoumi AM, Soon SL, et al. A catalog of dermatology utilities: a measure of the burden of skin diseases. J Invest DermatolSymp Proc 2004;9:160-8.

[41] Hay R, Bendeck SE, Chen S, et al. Skin diseases. In: Jamison DT, Breman JG, Measham AR, editors. Disease control priorities in developing countries. 2nd edition. New York: Oxford University Press; 2006; 707-22.

[42] Khatami A, San Sebastian M. Skin disease: A neglected public health problem. DermatolClin 2009;27:99-101.

[43] Schmeller W, Dzikus A. Skin diseases in children in rural Kenya: long-term results of a dermatology project within the primary health care system. Br J Dermatol 2001;144:118-24.

[44] World Health Organization. Guidelines for the management of sexually transmitted infections. Geneva: World Health Organization; 2001. WHO document WHO/RHR/01.10.

[45] World Health Organization. Improving child health. Integrated management of childhood illnesses: the integrated approach. Geneva: World Health Organization; 1997. WHO document WHO/CHD/97.12.

[46] Mahé A, Faye O, Thiam N'Diaye HT, Ly F, Konaré HD, Kéita S, et al. Definition of an algorithm for the management of common skin diseases at primary health care level in sub-Saharan Africa. Trans R Soc Trop Med Hyg 2005; 99:39-47.

[47] Porta N, San Juan J, Grasa MP, Simal E, Ara M, Querola I. Diagnostic agreement between primary care physicians and dermatologists in the Health Area of a Referral Hospital ActasDermosifiliogr. 2008;99:207-12. 